\title{
Preschool Religious Education in European Union Countries (Example of Vienna)
}

\author{
Abdullah Akin \\ Canakkale Onsekiz Mart University, Teology Fakulty, \\ Philosophy and Religious Sciences Department, 1700 Canakkale/Turkey \\ E-mail: abdullahakin@comu.edu.tr.
}

\begin{abstract}
According to the Federal Constitution's Article 14, in Austria, it is allowed that religious education is to be taught in schools, including children's nurseries and kindergartens. And also, religious communities could open schools. That is, churches and religious communities are authorized to teach religion within the general schooling system and according to legal possibilities. We can say that, the capital of Wien, the largest state of Austria, of nine states constitutes a perfect example in terms of private and municipal kindergartens. In Wien, some kindergartens attached to the municipality are completely free of fees, while for some, a small contribution is to be paid. There are also day care mothers and fathers (Tagesmütter und Tagesväter) and groups for children (Kindergruppen). Despite the existence of church organizations of Protestants and Orthodox Christians, Christian preschools are usually affiliated to the Catholic Church. There are also religious organizations for Jewish and Buddhists and kindergartens with religious education for children up to 3 to 6 years old. Muslims have the Islamic Religious Organizations (Islamische Glaubengemeinschaft). There are different kindergartens established by different associations and entrepreneurs such as Juwa and Funkelnstern by Muslims; Leben für lernen and Isma kindergatens by Austrian Muslims; Ifw, Wonder, Atib and Brotherhood schools that have preschool religious education at the weekends. Parents have the freedom to choose between the private or municipal (städtisch) kindergartens in Austria. The aim of this study is to reveal the relationship between changes and transformations at certain stages of its life and formal / non-formal education in social life by examining of these kindergartens' life story closely. In the study, the data collected through in-depth interviews, observation and document analysis were subjected to descriptive and content analysis.
\end{abstract}

Key Words: Austria, Wien, Islam, Mosque, Religious Education, Kindergarten.

Special Issue of Educational Sciences

DOI: $10.7176 /$ JSTR/6-06-01

\section{Avrupa Birliği Ülkelerinde Okul Öncesi Din Eğitimi (Viyana Örneği)}

Özet

Avusturya'da Federal Anayasa'nın 14. maddesi Anaokulları, çocuk yuvaları da dâhil okullarda din dersi eğitimi verilebilmesine ve dini cemaatlerin okullar açabilmelerine izin vermektedir. Yani, kiliseler ve dini cemaatler genel okul sistemi ve yasal imkânlar içerisinde din dersi vermeye yetkili kılınmıştır. Dokuz eyaletten oluşan Avusturya'nın en büyük eyaleti başkent Viyana'nın özel ve belediyeye bağlı anaokulları açısından tam bir örneklik teşkil ettiğini söyleyebiliriz. Viyana'da Belediyeye bağlı anaokullarının bir kısmı tamamen ücretsiz iken bir kısmı için çok küçük miktarda katkı payı ödenmektedir. Yanı sıra günlük bakıcı anneler ve babalar (Tagesmütter rund Tagesväter) ve çocuklara yönelik oluşturulan gruplar (Kindergruppen) da bulunmaktadır. Protestan ve Ortodoksların kilise teşkilatları mevcut olmasına rağmen, Hıristiyanlar anaokullarını genellikle Katolik kilisesine bağlı olarak açmaktadırlar. Bunun dışında Yahudiler ve Budistler'inde dini teşkilatları ve 3-6 yaşına kadar çocuklara din eğitimi verilen anaokulları mevcuttur. Müslümanların ise İslam Diyanet Teşkilatları (Islamische Glaubengemeinschaft) vardır. Müslümanların, “Juwa” ve

1 I $\mathrm{P}$ a g e

www.iiste.org 
"Funkelnstern" gibi farklı dernek ve Türk girişimcilerin kurduğu anaokulları; "Leben für lernen" ve "Isma” gibi Avusturyalı Müslümanların kurduğu anaokulları; "Ifw”, "Wonder", "Atib” ve "Kardeşlik Vakfı"na bağlı hafta sonu okulöncesi din eğitimi yaptıran okulları bulunmaktadır. Avusturya'da ebeveynler, özel (privat) veya belediyeye bağlı (städtisch) anaokulları arasında seçim yapma özgürlüğüne sahiptirler. Bu çalışmanın amacı, bu anaokullarının yaşam öyküsünü yakından inceleyerek, yaşamının belirli aşamalarındaki değişimler ve dönüşümler ile sosyal yaşamdaki örgün / yaygın eğitim arasındaki ilişkiyi ortaya çıkarmaktır. Araştırmada derinlemesine görüşme, gözlem ve doküman incelemesi yoluyla toplanan veriler, betimsel analize ve içerik analizine tabi tutulmuştur.

Anahtar Kelimeler: Avusturya, Viyana, İslâm, Cami, Din Eğitimi, Anaokulu

\section{Giriş}

Eğitimden, genel olarak, yetişmekte olan neslin ruhi ve bedeni bütün kabiliyetlerinin geliştirilmesi, sahip olunan değerlerin bir plana göre öğretilmesi ve yaşatılması anlaşılabilir. Başka bir deyişle eğitim, bir milletin değerlerini muhafaza eden ve olgunlaştıran çalışmaların bütünüdür (Ayhan, 1971, s. 409). Din eğitimi de din gerçeğine vurgu yaparak bireyin bir yaşam felsefesi geliştirmesine, yaratıcısına içten bağlanmasına ve iradî eylemlerinde O'nun buyruklarına uymasına öncülük eder. Din eğitiminin temel esprisi bireyleri din adına eğitmek ve onlara yaşanabilir birtakım davranış kalıpları kazandırmaktır (Zümrüt, 2006, s. 9). Son yapılan araştırmalar dinsel inançların güçlendiğini göstermektedir (Ayhan, 1992, s. 101). Din eğitiminin en önemli amaçlarından biri, İslâmî bir kimlik oluşturmaktır. Müslümanlar Batı'yla karşılaştıktan sonra bu kimlik vurgusu daha da öne çıkmıştır (Hıdır, 2008, s. 71).

İlk çocukluk evresi din ve din eğitimiyle tanışma evresidir. Çocuk, üç yaşından itibaren dini inançlarla ve dini nitelikli davranışlarla ilgilenmeye başlamasıyla, dini inanç gittikçe canlılık kazanmaya başlar (Şimşek, 2004, s. 215). Çocuklarda inançların yerleşmesinde, ibadet ve ahlaki davranışların sevilip samimiyetle yaşanmasında, anne-babanın rehberliği ve terbiyeci tutumları en önemli bir yer almaktadır (Ayhan, 1971, s. 409). Peygamber Efendimiz "Her doğan (çocuk) fitrat üzere doğar. Fakat annesi-babası onu kendi dinlerine döndürürler. Yahudi iseler; Yahudi, Hristiyan iseler; Hristiyan veya Mecûsi iseler; Mecûsi yaparlar” buyurmuştur (Buhari, Cenâiz, 79). Yani çocuk hangi rrk ve dine mensup anne ve babadan dünyaya gelirse gelsin, kendisine yapılacak inanç telkinlerini alabilecek ve terbiye esaslarını aynen benimseyebilecek kabiliyete sahip ve buna hazır olarak dünyaya gelmektedir (Öcal, 1996, s. 192). Müslüman ve Batılı eğitimciler de bu kanaati benimsemişlerdir (Kınalızade, 1313, s. 592; Smiles, 1975, s. 27; Çaplı 1973, s. 77). Batı'da Salzman, Kant, Locke ve Rousseau gibi birçok bilim adamına göre, çocukların kalbi bir mum gibidir ve eğitimci ona istediği şekli verebilir (Aydın, 2009, s. 21). Dolayısıyla okul öncesi dönemde çocuk, hangi davranışların iyi hangilerinin kötü olduğuyla ilgili ahlaki yargılar açısından başkalarına bağımlıdır (Koç, 2010, s. 649).

Çocukların genel terbiyeleri arasında dini terbiyeleri çok önemli bir yer işgal etmektedir (Öcal, 1996, s. 191). Buna göre çocuklar, başlangıçta çok temiz varlıklar olarak kabul edilmeli, iyi bir insan ve samimi bir Müslüman olabilme istidadının mevcudiyeti dikkate alınarak eğitilmelidir. Bu yöndeki çalışmaların en tesirlisinin ailede olacağını, hem yukarıdaki hadis, hem de bugünkü eğitim ilmi kabul etmektedir (Ayhan, 1971, s. 409). Dolayısıyla Doğduğu günden başlayarak çocuğun kişiliği önce ailesi, sonra okul ve yaşadığı çevredeki insanlar tarafından şekillendirilmektedir (Kaya, 1997, s. 193). Bu açıdan bakıldığında fitrat, insanlık kavramının muhtevasını veren ve ona uygun bir terbiye (eğitim) ve yaşayış biçimini gerektiren yaratılış keyfiyetidir, denebilir (Duman, 1991, s. 106).

Okul öncesi eğitim, insanın doğumundan ölümüne kadar hayatın her aşamasında eğitimle içi içe olması ve yaşamının en önemli yaşı olan 0-6 yaş arasında almış olduğu sistemli organize ve planlı eğitimin adıdır (Gelengül, 2010, s. 2). Genellikle tüm kültürlerde 2-6 yaşlar arası, sosyal ve ahlaki gelişimin en hızlı olduğu bir dönem olduğu (Köylü, 2009, s. 388) ve yaşamın şekillenerek belli bir ivme kazandığı dönem olarak kabul edilir (Apaydın, 2001, s. 319). Bu dönemde çocuğun iç motivasyonu, gelişim ihtiyacı karşılandığ 1 oranda oluştuğu için (Bolat, 2016, s. 205) inanmaya elverişli olan çocuğun sağlıklı ve dengeli bir biçimde ilgi görmesi gerekir (Aydın, 1996, s. 214). Çocuğun bütün gelişim basamaklarının temellerinin atıldığı ve büyük oranda şekillendiği bu dönem dinî gelişim açısından da oldukça önemlidir. (Apaydın, 2001, s. 332). Dinî gelişim, kişinin çocukluktan itibaren dinî hayatının basitten mükemmele doğru geçirmiş olduğu değişim sürecidir

2 I P a g e www.iiste.org 
denilebilir (Şentürk, 1997, s. 91). Bu nedenle çocuğun terbiyesi toplumsal değerlerle kaynaşacak bir tarzda gerçekleştirilmelidir. Toplumdan soyutlanarak, tek başına çocuğu terbiye etmek mümkün değildir; mümkün olsa bile, verimsiz ve süreksiz kalmaya mahkûmdur (Bayraklı, 2005, s. 185). Çocuğun dinî gelişiminde, kolay inanırlık, ben merkezcilik, antropomorfik (insan biçimci) özellikleri (Köylü, 2004, s. 138-139) ve Psikanalitik Yaklaşım kuramının öncüsü Sigmund Freud'un, 3-6 yaş arası çocukların geliştirdiklerini ileri sürdüğü süperego (üst benlik, bilinç, vicdan) dikkate alınmalıdır. Süperego çocukların biyolojik dürtülerine karşı direnebilmelerine ve toplumsal kurallar ile beklentilere uygun davranmaya başlamalarına yardımcı olmaktadır (Deniz, 2009, s. 286). Çocuklar bu dönemde sadece bedensel ve zihinsel açıdan değil, dini ve ahlâkî açıdan da önemli gelişmeler göstermekte ve bu dönemde kazanılan tutum ve davranışların etkisi, hayat boyu devam etmektedir (Köylü, 2009, s. 407: Karaköse, 2010, s. 26; Ay, 2013, s. 567; Heinelt, 2003, s. 210). Bu dönemde ister dini olsun ister olmasın bireyin bütün tutum ve davranışlarının arkasında aile önemli bir etken olarak ön plana çıkmakta (Argly, 1978, s. 7) ve toplumun kültür ve medeniyet alanında yükselmesi, çocukların eğitiminin önemsenmesine bağlı görünmektedir (Aydın, 2003, s. 157). Bu yüzden dini kişiliğin oluşumunda etkisi yadsınamaz olan dini uyanışın çocukta aile üyelerinin ilgi, teşvik ve örnek dini davranışlarıyla gerçekleşmesi gerekmektedir (Aydın, 2003, s. 112).

Araştırmalar çocuktaki dini duygu ve düşüncenin gelişmesinin bu dönemde aldığı dini eğitime bağl1 olduğunu göstermektedir (Armaner, 1980, s. 89; Yavuz, 1983, s. 46; Öcal, 1991, s. 75). Eskiden beri bilinegelen bu gerçek, bugün çocuk ve din psikologları tarafından bilim dallarında yapılan araştırmalarla desteklenmiştir (Ay, 1994, s. 163). Bu eğitimde çocuklar neyin doğru neyin yanlış olduğunu, kendilerine kesin ve belirgin şekilde neyin doğru ve neyin yanlış olduğunun söylenmesi ve bu direktiflerin ödül ve cezayla sıkça pekiştirilmesiyle öğrenirler (Traughan, 2008, s. 21). Bununla birlikte okul öncesi dönemde din eğitimi ilköğretim dönemi çocuklarına uygulanan ders ve sınıf mantığıyla hazırlanmış haftanın belli bir saatinin din eğitimine ayrılması şeklinde anlaşılmamalıdır. Bu dönemde, sözlü öğretim, oyun, taklit, özbakım, pratik beceri, bireysel yetenek ve sanatsal kabiliyet geliştirme şeklinde, çocuğun diğer gelişim alanlarıyla beraber dini ve ahlaki gelişimlerini de hedefleyen nitelikte etkinlikler yapılmalıdır (Sağlam, 2013, s. 557).

Çocuğun evde öğrendikleri bilgilerle okulda öğrendiği bilgilerin çatışmaması, birbirini destekler ve tamamlayıcı olması da önemsenmesi gereken diğer bir konudur. Eğer çocuğun aile içinde öğrendiği bilgilerle okulda öğrendiği bilgiler çatışırsa, çocuğun öğrenmesi ve okul bilgilerini başarması zorlaşır (Doğan, 2010, s. 28). Özellikle sağlıksız şartlar ve ortamların anne ve babanın çocuk üzerindeki etkinliğinin azalmasına sebep teşkil edebileceği de göz önünde bulundurulursa, çocuğun okulöncesi 0-6 yaş arasındaki çocukluk dönemi, ailenin evlatlarına verecekleri eğitim ve öğretimin ihmal ile geçiştirilmemesi gereken bir dönem olduğu anlaşılacaktır. Bu nedenle ebeveyn, çocuk psikolojisine dair bilgiler edinmeli ve çocuğun ruhi yapısını tanımaya çalışmalıdır (Ay, 2005, s. 335). Ailesinin yardımıyla çocuğun dini duyguları zamanında geliştirilirse zamanı gelince, bireysel ve toplumsal vazifelerini daha rahat bir şekilde yerine getirmeye başlayacaktır (Duman, 1991, s. 110).

Piaget'nin işlem öncesi dönem olarak isimlendirdiği altı yaşa kadar olan bu evredeki çocuklar, zihinsel güçleri gelişmesine rağmen olayları anlamada ve çözümlemede zorluk yaşarlar (Bilgili, 2005, s. 41) ve bu devrede (2-6 yaş) bilinçli veya bilinçsiz olarak davranışları ve gelenekleri taklide ve tekrara başlarlar. Öyle ki taklit yalnız hareketlerde olmaz, duygular ve heyecanlar da taklit edilir (Armaner, 1980, s. 82). Bir başka deyişle taklit yoluyla çocuk, fotoğraf makinesi gibi, gördüğ̈̈ her şeyi çeker ve zamanı gelince de tab edip ortaya çıkarır (Özbek, 2010, s. 336). Aile çocuğun, ne gibi duygu, düşünce ve davranışlara sahip olduğunu bilirse, çocuğun müsait olduğu zamanlarda yapılacak telkinlerle, bilhassa iyi örneklerle, dini yaşayışı severek kazanmasını temin edebilir. Dolayısıyla ebeveynler çocuğun günlük yaşayışı içinde din esaslarını birer nazariye olarak anlatmaktan çok, bizzat vereceği örneklerle benimsemesini sağlamalıdır. Mesela anne-baba yemekten önce çocuğun ellerini yıkamasını, "besmele" ile yemeğe başlamasını öğretmek istiyorsa, bunu her zaman ve ihmal etmeden kendileri yapmalı (Ayhan, 1971, s. 409) ve çocuğun o yaşlarda hareketlerini dikkatli bir şekilde takip ettiklerini ve taklit etmeye çalışacaklarını unutmamalıdır. Çünkü akıl yürütmeden şartlanma ile hangi davranışlarının kötü ve iyi olduğunu sezmeye çalışan çocuk, anne babayı veya evdeki diğer büyükleri memnun etmek için, iyi olan davranışları, onların hoşuna giden hareketler olarak kabul edecektir (Başaran, 1971, s. 158). 
Çocuk özellikle okul öncesi dönemde kendini özdeş tutacağı model olarak anne ve babasını alır. Onların değer yargılarını benimser, konuşma ve davranışlarını taklit eder. Bu taklit din eğitimi alanında da görülür. Mesela çocuğun, namaz kılanları taklit etmesi, sahura kalkmak istemesi, ailenin çocuğu dini yönden etkilemesi, onun, dinî değerlerin ve dinî ilişkilerin modeli olmasından ileri gelmektedir (Bayraktar, 1995, s. 135). Taklitle başlayan din, çocuğun kendi kabiliyetine, ailenin ve çevrenin dinî atmosferine göre yavaş yavaş gelişip derinleşerek dinî yaşayışa dönüşür (Kılavuz, 2005, s. 56). Bundan dolayı ailede dinî hayatın canlı tutulması ve çocuklara örnek olunması için, anne-babaların İslâm'ın inanç esasları açısından doğru (sahih) iman çizgisinde olmaları önemli bir husustur (Sağlam, 2006, s. 169).

Okul öncesi çocukluk dönemi ile ilgili giriş mahiyetindeki bu bilgilerden sonra, öncelikle Viyana eyaletinin bulunduğu Avusturya'da din eğitimi için tanınan anayasal haklardan bahsedilecektir. Daha sonra çalışmanın konusunu oluşturan Avrupa ülkelerindeki okul öncesi din eğitiminin, Viyana özelinde yapılan araştırmayla günümüze yansımaları değerlendirilecektir.

Fransa gibi laik düşünceyi hükümet politikası olarak uygulayan bu ülke dışındaki Avrupa ülkeleri hükümetleri, insanın dine olan ihtiyacını hassasiyetle kabul edip bu konuda insanlara imkânlar sunmayı bir görev saymaktadırlar (Bolay, ve Türköne, 1995, s. 53). Avrupa Kıtası'nda İslam'ı din olarak resmen tanıyan iki ülke Avusturya ve Belçika'dır. Federal yapıda parlamenter bir cumhuriyet olan Avusturya Cumhuriyeti (Republik Österreich) geniş yetkilere sahip kendi kanunlarını meclisleri tarafindan çıkaran dokuz eyaletten meydana gelmektedir (Tavukçuoğlu, 1994, s. 65). Din-devlet ilişkisini belirleyen temel nokta, Temel Vatandaşlık Hakları Anayasasının 15. maddesinde yer alan eşitlik prensibidir. $\mathrm{Bu}$ yasal sistem iki temel prensip üzerine kurulmuştur. Birincisi, dinî ve felsefî inançlar konusunda bireysel özgürlük hakkı; ikincisi ise, dinî toplulukların kamuda toplu faaliyet hakkıdır (Potz, 2008, s. 81). Federal Anayasa'nın, okullarda din dersi eğitimi verilebilmesine ve dinî cemaatlerin okullar açabilmelerine izin veren 14. maddesi şöyledir:

Devlet okulları doğum, cinsiyet, ırk, statü, sınıf, dil, din ve kanuni gereklilikler sınırları dâhilinde başka her hangi bir ayrım olmaksızın herkese açıktır. Anaokulları, çocuk yuvaları ve öğrenci yurtları için de aynı hüküm geçerlidir.

Bununla birlikte din eğitimi, Anayasa'nın 17. maddesinin 4. fikrasıyla teminat altına alınmıştır. Buna göre, Devletin tanıdığı bir kilise veya cemaatin mensubu olan tüm öğrenciler için, bunların kendi mezheplerinin esas alındığı din derslerinin ilkokul ve ortaokullar ile eğitim, ziraat ve orman kolejleri müfredatlarında bulunması zorunludur. Yani, kiliseler ve dini cemaatler genel okul sistemi ve yasal imkânlar içerisinde din dersi vermeye yetkili kılınmıştır. Ek Protokol'ün (ECHR) 2. maddesi gereğince de velilere, çocuklarının dinî veya felsefî eğitim almalarına karar verme hakkı tanınmıştır (Şencan, 2012, s. 80; Potz, 2008, s. 81). Avusturya'da Mezhepler ve tarikatlar hakkında sorusu olanlar için danışma fonksiyonu üstlenen "İnanç Meseleleri Federal Ofisi”" adlı bir federal kamu kurumu da bulunmaktadır (Şencan, 2012, s. 77).

Avusturya'daki her dinî cemaatin devlet tarafından tanınan resmi bir teşkilatı vardır. Dini cemaatler ibadet, eğitim ve sağlık gibi organizasyonlarını bu dinî teşkilatlar aracılığı ile yapmaktadırlar. Mesela Viyana'daki Katolik, Protestan ve Ortodoksların kilise teşkilatları olduğu gibi, Müslümanların da İslam Diyanet Teşkilatı vardır. Bunların dışında Avusturya'da Yahudiler ve Budistler de yaşamaktadır. Bu dinlere mensup olanların teşkilatları da resmen tanınmaktadır (Tavukçuoğlu, 2000, s. 28).

Anayasanın tanıdığı bu haklar doğrultusunda, Avusturya'da cemaatler, devlet tarafindan tanınan resmi teşkilatlar kurmuşlardır. Bu dinî cemaatler ibadet ve eğitim gibi çalışmalarını kurdukları bu teşkilatların çatısı altında yapmaktadırlar. Makalede, genel bir örneklik teşkil etmesi açısından Viyana'daki Katolik Kilisesine ve Belediyeye bağlı anaokulları ile Müslümanların kurduğu örgün ve yaygın anaokulları ele alındı. Gerekli resmi izinleri aldıktan sonra aşağıda detaylı bir şekilde görüleceği üzere, bu okullarla röportajlar yapıldı ve yerinde incelemelerde bulunuldu.

\section{Katolik Kilisesine Bağlı Anaokulları}

Bu günkü anlamda ilk anaokulu 1620 Amerika'da, 1640 y1lında Avrupa'da Fransa, İngiltere, Almanya ve Hollanda gibi ülkelerde açılmaya başlamıştır (Diken, 2014, s. 16). Günümüzde halkının \%73,6'sı Roman Katolik mezhebine mensup olan Avusturya'da ise anaokulları doğal olarak bu mezhebe bağlı olarak açılmaktadır. Katolik kilisesine ait St. Nikolaus Vakfı bünyesinde yalnızca Viyana genelinde 80 tane Anaokulu ve ev ödevlerine yardım kursları bulunmaktadır. Bu kurumlarda toplamda okuyan 0-10 yaş arası 6000 çocuğa 850 öğretmen ve pedagogla hizmet

4 I P a g e 
verilmektedir. Bu okullardan Embelgasse 5-7 1050 Wien adresinde bulunan "Kirchlicher Kindergärten Der Pfarre Auferstehung Chiristi" Anaokulu Müdiresi yaptırılan mülakata (Güner, 2017, s. 129-130) göre, Katolik Kilisesine bağlı anaokullarında uygulanan din ve ahlâk eğitimi hakkında öğrenilen bilgiler şu alt başlıklarla özetlenmiştir:

\subsection{Din eğitimi}

Bu eğitim merkezlerinde çocuklara dini bilgiler, - katılım için anaokulu mevzuatına göre ailelerin onayı alındıktan sonra - Weihnachten (İsa'nın doğum yortusu), Heilige Drei Könige (Acı su yortusu), Ostern (Paskalya), Christ Himmelfahrt (İsa’nın Gökyolculuğu), Pfings Montag (Hamsin Yortusu), Aschen Kreuz (Kül Çarşambası) gibi dinî gün ve bayramlar da verilmektedir. Ayrıca Kül Çarşambası adı verilen ayin, papaz eşliğinde yapılır ve bir önceki Palmiye Pazarında yakılan yaprakların küllerinden cemaatin alnına külden haçlar çizilir. Bu günlerde anaokulunun belirlediği birkaç ebeveyn çocuklara anaokulunun belirlediği kitaplardan dini hikâyeler okurlar. Zaman zaman kilise ziyaretine götürülen çocukların yılsonu programı da kilise de yapılır. Özellikle Paskalya Yortusunda ebeveynleri ile kiliseye giden çocuklar âyine katılmasalar da öğrendikleri Hıristiyanlık dualarını sunarlar.

\subsection{Günlük programı}

07.30'da açılan okula veliler çocuklarını en geç 09.00'da teslim etmek zorundadırlar. 07.30-09.00 arası çocuklar küçük gruplar halinde serbest oyunlar oynarlar. 09.00-09.30 arası yemek yenir. Yemeğe başlamadan önce toplu halde yemek duası yapılır. Yemekten sonra saat 12.00'ye kadar çocukların fiziki ve ruhi gelişimleri için çeşitli aktiviteler yapılır. Bu aktivitelerle çocuklara yaşantıları boyunca kullanacakları yemeklerden sonra diş firçalama, izinsiz yerinden kalkmama, izinsiz dışarı çıkmama, dağıttıkları oyuncakları kendilerinin toplamaları, kendilerinin giyinmesi vb. ahlak ve sağlık kuralları da öğretilmektedir. 12.00 'de yenilen öğle yemeğinin hazırlığı çocuklarla beraber yapılır. Çocuklar yemekleri kendileri seçerler ve yemekten sonra ortalığın temizliğine ve sofranın toplanmasına yardım ederler. 13.00 çocuklar için dinlenme saatidir. Çocuklar bir müddet sınıf içerisinde serbestçe oynarlar. Hava güzel olursa çocuklar parka götürülür. 14.30-15.00 arası Jause saati (Atıştırmalık saati), 15.00-16.00 arası ise pedagog ve öğretmenler gözetiminde serbest oyun ve eğlence saatidir. 16.00'dan itibaren çocukların anaokulundan almaya başlarlar ve en geç saat17.00'de veliler çocuklarını anaokulundan almak zorundadırlar.

\section{Belediyeye Bağlı Anaokulları}

Avusturya'da nicelik olarak en yaygın anaokulları belediyelere bağlı M.A. 10 - M.A. 11 anaokullarıdır. Bu okullar ile ilgili bilgi edinmek üzere 2016 yılında resmi makamlardan, MA10 "Wiener Kindergärten (Viyana Anaokulları Müdürlüğü)", MA11 "Ams für Jugend und Familie (Viyana'daki tüm belediye ve özel anaokulları için yetkili makam)" ve "Stadtschulrat in Wien (anaokulları ile yetkili okul kurulu)"e resmi başvuruda bulunuldu. Ancak resmi görüşme talepleri kabul görmedi. Bunun yerine faydalanabilecek çeşitli resmi internet sitelerine yönlendirdiler (Güner, 2017, s. 131-141).

$\mathrm{Bu}$ sitelerde ise daha çok, tarihsel gelişim, kayıt şartları ve resmi işlemler ile ilgili bilgiler mevcuttur. Buna göre, Viyana'da bulunan tüm anaokulları ile zorunlu eğitimin tamamı ücretsiz ya da çok küçük miktarda katkı payı bulunmaktadır. Çünkü Viyana Belediyesi, ebeveyn yardım programını desteklemektedir. Çocuklara yönelik oluşturulan gruplar (Kindergruppen), aile yapısına benzer geliştirilmiş bir bakım biçimidir. Bir grupta aynı zamanda en fazla 14 çocuğa bakım hizmeti verilmektedir. Bu gruplar, bir kadın ya da bir erkek çocuk bakıcısı tarafından yönetilmektedir. $\mathrm{Bu}$ konuda pedagojik olarak farklı konulara ağırlık veren birçok aktivite bulunmaktadır. Bu sitelerden bazılarına şu adreslerden ulaşılabilir. (https://www.wien.gv.at/ bildung/ kindergarten /pdf/ bildungs plan.pdf; www.ris.bka.gv.at/GeltendeFassung.wxe?Abfrage=LrW\&Gesetzesnummer=20000263;). Ayrıca Belediye okullarında çalışan eğitmen E. M. G. ile yapılan görüşmeye göre okulların günlük programı şu şekildedir:

\subsection{Günlük program (Tagesablauf )}

Avusturya da belediye anaokulları, Pazartesi, Salı, Çarşamba, Perşembe ve Cuma 07.00-17.00 saatleri arasında hizmet vermektedir. 06.00 'da açılan okula veliler çocuklarını en geç 06.00-07.00 saatleri arasında getirirler. 07.00-08.30 arası her grubun kendi pedagogu çocuklarını alıp grubuna geçer ve çocuklarla küçük gruplar halinde serbest oyun oynarlar. 08.30-09.00 arası yapılan

5 I P a g e www.iiste.org 
kahvaltıdan sonra saat 11.45 'e kadar çocuklarla bireysel (yoğun) çalışmalar yapılır. Çocukların fiziki ve ruhi gelişimleri için yapılan bu çeşitli aktiviteler, serbest oyun, küçük gruplarla çalışma, pedagojik çalışma, Sitzkreis (daire şeklinde oturma), bahçeye çıkma, dışarıya çıkma şeklinde gerçekleştirilir. 11.45 'te öğle yemeğine hazırlık ve el yıkamadan sonra, 12.00'da öğle yemeği yenir. $\mathrm{Bu}$ arada okula yarım-gün devam eden çocuklar velileri tarafından alınır. 12.20 - 13.45 arası çocukların dinlenme vaktidir. 14.00’te çocuklar uyanır ve çocukların bir kısmı veliler tarafından alınırken, tüm gün kalan çocuklar için Jause (Atıştırmalık) zamanıdır. 15.00-16.00 arası çocuklar ister serbest ister bahçede pedagojik uzmanlar kontrolünde oyun oynarlar. 17.30'da anaokulu kapanır.

\section{Müslümanların Kurduğu Örgün Anaokulları}

Bu kurumları incelemeye geçmeden önce, 1964 yılında “misafir işçi” olarak Avusturya'ya gelmeye başlayan birinci neslin manevi ihtiyaçlarını karşılamak için yaptığı ilk çalışmalardan bahsetmek gerekir. Avrupa'ya işçi olarak giden Türklerin \%80'i kırsal alanlarda doğup büyümüş, büyük şehirlerde gecekondu semtlerinde yaşamış, eğitim seviyeleri düşük insanlardır (Sezgin, 1992, s. 49). 1960'lı yıllardan başlayarak Almanya, Belçika, Hollanda, Avusturya, Fransa ve İsveç gibi Batı ülkeleriyle karşılıklı anlaşmalar imzalanır ve bu istikamette bu yıllardan itibaren Batı'ya göç hareketleri de başlar (Çetintaş, 2011, s. 57).

Başlangıçta büyük zorluklarla karşılaşan ilk nesil Müslümanlar, zamanla dinî ihtiyaçlarını gidermek üzere ferdi planda ve gruplar halinde çalışmalara giriştiler. Öncelikle cuma, teravih ve bayram namazlarını kılabilecekleri geçici yerler kiralamaya, daha sonrada ibadetlerini devamlı yapabilecekleri, çocuklarına eğitim öğretim verebilecekleri camiler ve dernekler açmaya başladılar. Din eğitimi çalışmalarını ise evlerinde başlatmışlardır. Gönüllülük esasına dayalı olarak yapılan bu çalışmalarda sayı arttıkça yapılan eğitim çalışmaları, daha sonraları sınıf ortamından uzak ve öğrenciyi öğrenmeye motive eden bir düzenlemeden yoksun namaz kılınan mekânlara taşınmıştır. Yapılan bu çalışmaların giderlerinin tamamı birinci neslin yapmış olduğu mali desteklerle yürütülmüştür.

Farklı bir kültürün içinde bulunma, azınlık psikolojisinin vermiş olduğu savunma hali, dışlanma, horlanma, ayrımcılık gibi faktörlerin de rol oynamasıyla Avusturya'daki bu ilk Müslümanlar, dinî inanç ve milli kültürlerine daha sıkı sarılma ihtiyacını hissetmişlerdir. Bu nedenle, farklı şehirlerde açılmaya başlanan camileri oluşturanlar 70'li yılların başından itibaren sadece bulundukları yerlerde bu çalışmayı yapmanın yeterli olmadığının, birlikte çalışmaları gerektiğinin farkına varmışlar ve Avusturya genelinde teşkilatlanma çalışmaları başlamıştır. Böylece değişik dinî STK'lar kurulmuş, bu STK' lar kendi mensuplarının dinî, sosyal ve kültürel ihtiyaçlarını karşılamak için hizmet vermeye başlamışlardır. Yanı sıra Avusturya'da İ́lam dininin resmen tanınmış olması sebebiyle, Müslümanların dinî hizmetlerinin bir bölümü devlet tarafından karşılanmaya başlanmıştır. Bu yıllarda cami bünyesinde oluşturulan sınıf ortamlarının kalitesi artırılmış, sıraları, televizyonu, bilgisayarı, yazı tahtası, sinevizyonu ve panoları bulunan hatta akıllı tahtası olan tam teşekküllü sınıflar oluşturulmuştur. Bununla da kalınmamış öğrencilerin teneffüslerde kullandıkları mekânlar oluşturulmuştur.

Günümüzde ise önceden planlanan, mimarisi düşünülen, estetiğe önem verilen, içine girildiğinde size geldiğiniz yerin anlamını anlatan mekânların temelden inşa edilme süreci başlamıştır. Cami anasınıflarında hizmet veren mekânlarında büyük ölçüde anaokullarından farkı kalmamıştır. Bu alanda mekânların sırası, masası, sandalyesi, kitaplığı, lavabo ve WC vb. malzemeleri hususunda aynı standartlar sağlanmıştır. Bu mekânlarda oyun sahaları ve programların organize edildiği salon imkânları oluşturulmuştur. $\mathrm{Bu}$ kısa açıklamadan sonra Müslümanların kurdukları örgün anaokulları, yapılan görüşme ve inceleme sonuçlarına göre aşağıda detaylı bir şekilde verilmiştir.

\subsection{Juwa Kindergarten Gruppen (Juwa Anaokulları)}

IGMG (Islamische Gemeinschaft Millî Görüş / İslam Toplumu Millî Görüş)'e bağlı IFW (Islamische Föderation in Wien / Viyana İslâm Federasyonu) bünyesinde Viyana genelinde asıl öğretmenlerinin tamamı Avusturya'lı pedagoglardan oluşan 6 tane Anaokulu bulunmaktadır. IFW Juwa Kindergärtenlarının Kurucu Başkanı Mesut Koca ile bu okulların kuruluşundan günümüze kadar yaşadıkları gelişmeleri öğrenmek üzere bir mülakat gerçekleştirildi. (Güner, 2017, s. 139154). Bu görüşmede anaokullarında uygulanan din ve ahlâk eğitimi hakkında öğrenilen bilgiler özetle şöyledir: 


\subsubsection{Kuruluşu ve Amacı}

Bu okulların ilki, çocuklara dinî bir alt yapı hazırlamak ve İslam kültüründen uzaklaşmalarını önlemek, büyük bir kültür erozyonu ve yıkımına karşı çocukları korumak ve helal gıda ile beslenmelerini sağlamak amacıyla 2007'de açılmış ve kısa sürede rağbet görmüştür. İlk kuruluşunda büyük sıkıntılar yaşanan bu anaokulu, uzun süre devlet tarafindan takip edilmiş, sonunda yetkililer okulun sistemli çalıştığına ve başarılı olduğuna ikna olunca diğerlerinin açılışına da izin vermiştirler.

\subsubsection{Eğitimcilerin Nitelikleri}

Başlangıçta bütün Kindergärten şubelerinde çocuklara grup halinde din eğitimi yaptıran öğretmenler hizmet vermekteydi. Hatta bunların içinde gezici kültür ve din öğretmenleri de mevcuttu. Bu öğretmenler, her gün bir şubeye gidiyor, çocuklara sözlü olarak, cd ve mp3 formatındaki ses dosyaları desteğiyle sureler, dualar ve ilahiler öğretiyorlardı. Bu okullardaki din eğitimcisi kalitesi IFW'ye bağlı kız öğrencilere yönelik, dört yıllık akademik eğitim veren "Islamisches Institut In Österreich / Avusturya İslâm Enstitüsü" mezunlarının öğretmen olarak atanması ile artmıştır. Din eğitimi dışındaki öğretmenlerin tamamı ise Avusturya'lı pedagoglardan oluşmaktadır.

\subsubsection{Veli Eğitmen Diyaloğu}

Bir eğitim ve öğretim yılında kurum ve veli iş birliğini geliştirmek maksadıyla ilki eylül ayında olmak üzere dört veli toplantısı yapılır. Günlük problemler, veli çocuğunu almaya geldiğinde veya telefonla konuşularak çözülmeye çalışılır. Veli ve eğitmen arasında, çocuk gelişim konuşması adı verilen zorunlu ve daha detaylı bilgi alış verişi ise önceden belirlenmiş bir günde uzun uzadıya yapılır. Okulda her grubun kendine ait duvarında velilerin takip etmek zorunda olduğu posta kutusu bulunur. Anaokulu veliden çocuğunu vaktinde ve düzenli bir şekilde okula getirmesini, gelemediği takdirde bunu kuruma bildirmesini beklemektedir. Ayrıca çocuklara evde eğitimi özendirici şeyler sunulması, temizlik ve sağlık bilgisi verilmesi ve çocukları mevsime göre giydirmeleri tavsiye edilmektedir.

\subsubsection{Pedagojik Çalışmalar}

Anaokuluna kayıt olan her çocuk için eğitim dönemi başında gelişim plan dosyası hazırlanır. Buna "Bilgi Ağacı" denir. Bu sayede çocuğun sene başındaki durumu ile sene sonundaki durumu karşılaştırılıp çocuğun gelişimi hakkında daha detaylı bir bilgi veli ile paylaşılır. Avusturya müfredatına göre planlanan pedagojik çalışmalarla, çocukların sosyal, duygusal ve bilişsel gelişimleri değişimleri gözlenir. Çocukların toplum içinde sorumluluk sahibi, bağımsız ve olgun olmaları desteklenir. Bu pedagojik çalışmalarını, beden, spor, sağlık, sosyal ve kültürel çevre, iletişim, resim ve duyular, müzik, matematik temel bilgiler, doğa bilimi ve teknik temel bilgiler, trafik eğitimi oluşturmaktadır.

\subsubsection{Dil eğitimi}

Dilin kişiliklerin oluşmasında, çocukların sosyalleşme ve kültür sahibi olmasın da çok büyük payı vardır (Arslantürk, 2008, s. 158). Anaokuluna kayıt olan çocuklar genelde azınlık çocukları olduğundan okula başladıklarında, iyi derecede Almanca konuşmaları hedeflendiği için dil eğitimi, bu anaokullarında önem açısından en üst sıralarda yer almaktadır. Almanca dili, bu okullarda duyularla daha iyi kavranabilmesi için oyunlarla öğretilir.

\subsection{6. Özel Günler ve Bayramlar}

Çocuklar, Avusturyalıların özel gün, gece ve bayramlarına özenti duyuyorlar, bu da Müslüman aileler açısından büyük bir sıkıntı oluşturuyor. Bu nedenle bu anaokullarında İslâm dininin öngördüğü, özel gün, gece, bayram günleri büyük bir coşkuyla kutlanmaya çalışılmaktadır. Bu günlerde o günleri ifade eden ve anlatan afişler, fişler, şekiller, süslemeler ve maketler yapılmaktadır. Doğum günlerine alternatif programlar ve kutlamalar düzenlenmektedir. Ayrıca cami, doğa ve kültür gezileri de sürekli ve düzenli olarak yapılmaktadır.

Örneğin, Ramazan Bayramında, çocuklara bayram kartları hazırlanır. Sınıflar süslenir. Anaokulundaki bütün sınıfların katılımı ile bayram programı hazırlanır ve veliler davet edilir. Programa çocukların okuduğu Kuran-1 Kerim ile başlanır ve çocuklar tarafindan şiir ve ilahiler okunur. Çocuklar önce öğretmenleri ile sonra da arkadaş ve aileleri ile bayramlaşırlar. Program 
sonunda çocuklara hazırlanan hediye paketleri verilir ve velilere ikram yapılır. Kurban Bayramında, Ramazan Bayramı programına ek olarak çocukların kurbanı anlamaları için kurban ibadeti anlatılır ve öğlen yemeğinde kavurma ikram edilir. Hac ibadeti ise anlatıldıktan sonra, maketler üzerinde çocukların anlayabileceği şekilde pratik olarak gösterilir.

Kandil gecelerinde de yine çocuklara konuya uygun kartlar hazırlanır. Çocuklara Salavat-1 şerife öğretilir ve gün içinde hep beraber sık sık söylenir. Özellikle Mevlit Kandilinde gül takdim edilir. Diğer günlerden farklı hazırlıklar yapılır. Kadir gecesi gününde çocuklara sık sık Kadir Süresi okutulur. O güne özel anaokuluna Kur'an tilaveti güzel bir hoca davet edilir veya CD'den dinletilir. Miraç kandilinde çocuklara miraç hediyesi olan Bakara Suresinin son iki ayeti (amenerrasulu) dinletilir ve toplu olarak okunur. Namazın nasıl kılındığ 1 anlatılır ve gösterilir. Recep ve Şaban ayında ramazan ayının geldiği ve çok önemli bir ay olduğu hatırlatılır. Çocuklar bu kandil günlerinde isterlerse anaokuluna başörtülü gelebilirler.

$\mathrm{Bu}$ kurumlarda yukarıda ifade edilen etkinliklerin olması din eğitimi açısından çok önemlidir. Ancak burada anne-babalara da ailede iş düşmektedir. Şöyle ki, ebeveynler çocukları, beğendikleri iyi ve güzel davranışları yaptıkları zamanlarda, bu davranışlarından dolayı Allah'ın ve Peygamber'in onları seveceğini söylemeli, anlayabileceği miktarda dini bilgiler vermelidir. İbadetlerin çocuklara öğretilmesi de aynı metodla yapılmalıdır. Namaz ve orucu sevdirmeli, çocuklar namaz ve oruca başladığı zamanlarda, hediyeler almalı, bu hareketlerinden dolayı, büyükler memnun olduklarını söz ve tutumlarıyla, çocuklara anlatmalıdır. Dini gün ve gecelerde, çocukların beğeneceği yiyecek, giyecek ve oyuncaklar alarak, o gün ve gecenin özlemini duymalarını, geçtikten sonra da elindeki oyuncağı gördükçe, kendine bu çok sevdiği oyuncağın alınmasına vesile olan günleri severek hatırlamaları sağlanmalıdır (Ayhan, 1971, s. 412).

Dini günlerin yani Ramazan ayı, iki dini bayram (ramazan ve kurban bayramı) ve kandil günlerinin, çocuğun manevi hayatında uyandıracağı atılımlar oldukça önemlidir. Hatta bu günlerle ilgili dini hikâye ve menkıbelerin anlatılması, çocuğun dine karşı ilgisinin artmasına neden olacaktır. Çünkü çocuğa sıcak ve okşayıcı dinî hikâyeler, menkıbeler ve buna benzer şeylerin anlatılması ve gözlemleriyle idrak ettiği sayısız olayların etkileri, onun henüz çok taze ve işlenmeye hazır ruhuna yayıldıkça, o bu dönemde dine karşı içinde gittikçe artan bir ilgi duymaya başlayacaktır (Peker, 1985, s. 47). Kuran-1 Kerimde eğitim yöntemi açısından birçok kıssalar vardır. Bu hikâyeler çocuğun bilişsel, duyuşsal ve davranışsal gelişimine katkı sağlayacak şekilde kullanılabilir (Ay, 2001, s. 22).

\subsubsection{Din eğitimi}

Okul öncesi din eğitiminde oyunun özel bir yeri vardır. Bu nedenle ilk Çocukluk Evresine (2 - 6 yaş) “Okul Öncesi” veya “Oyun Çağı” adları da verilmektedir (Öcal, 1991, s. 63). Çocuk eğitiminde oyundan yararlanılır. Özellikle grup oyunların ve oyunda üstlenilen roller kişiliğin gelişmesine yardım eder. Sağlıklı bir çocuğun oynaması ve oyunlara katılması beklenir. Çocuklar genelde grup oyunu oynamaktan zevk aldıkları halde, bazıları yalnız oynamaktan hoşlanırlar, dolayısıyla onları zorlamamak gerekir (Bayraktar, 1995, s. 120). Carsora bu dönemde oyunun önemini şöyle vurgulamaktadır: "Okul öncesi dönemdeki akran grupları ve oyun grupları çok önemlidir. Çünkü çocukları aynı konumdaki kişilerle bir araya getirerek, aile ortamında görülmeyecek deneyimler sağlayacaktır" (Gülay, 2010, s. 51). Çocuklar oyundan mahrum bırakılmamalıdır. Bilhassa onları oyun oynamaya teşvik etmelidir.

Oyun çocuğun hem bedenini hem ruhunu hem de kişiliğini geliştirir. Eğer çocuğa oyun ve eğlence firsatı verilmezse çocuğun birçok yeteneği, birçok ruhi hasletleri elinden alınmış olur (Kafkasyalı, 1997, s. 179). Atalarımız bunu ifade etmek için "Oynamayan tay at olmaz" demişlerdir. Montaigne'nin yüzyıllar önce belirttiği gibi "çocukların oyunu, oyun değil, onların en ciddi uğraşıdır." Okul yaşına gelmemiş çocukları kısa bir süre gözlemlemek bu gerçeği ortaya koymaya yeter. Çocuklar gün boyunca durup dinlenmeden oynarlar. Kendilerini oyuna öylesine kaptırırlar ki acıktıklarını bilmez, çağrılınca duymazlar (Yörükoğlu, 2002, s. 66).

Çocukluğun ilk yıllarındaki sevgi ve güven ihtiyacı, gıda, dinlenme ve oyun ihtiyacı gibi ihtiyaçların engellenmesi veya tatmini esnasındaki zorluklar, çocuğa güvensizlik verir (Çamdibi, 2005, s. 127). Keza devamlı yardım alan çocuk özgüvenini kaybeder (Girgin, 2012, s. 114). Rasulullah'ın yaşantısı, emir ve tavsiyelerine bakıldığında ailedeki sevgi eğitiminin çok önemli olduğu görülmektedir (Gözütok, 2002, s. 208). Kant da dini değerlerin öğretiminin bask1 ve cezac1 yönteminden ziyade sevgiye dayalı verilmesini savunur. Jacquin ise çocuğun temiz havaya olan 
ihtiyacını sevgiyle eşit görmüştür (Jucquin, 1996, s. 51). Çocukların en temel ihtiyaçlarından biri olan sevgi, onların doğru bir kişilik gelişiminde ve güven duygusunu kazanmasında çok etkin bir yeri vardır. Kişilik ise kişiye dair davranış, düşünüş ve hissediş motifleridir (Girgin, 2006, s. 14). Yunus Emre'nin dediği gibi: "Sevgi gelince bütün eksiklikler biter" (Gül, 2006, s. 90). Ev içindeki anne ve babanın birbirlerine gösterdikleri sevgide aynı derecede önemlidir (Kaya ve Uzunoğlu, 2012, s. 39).

Müslümanların açmış olduğu bu kurumlarda, din eğitimi özel eğitmenler tarafindan çocuklara yemek yeme, su içme, giyinme, tuvalet, konuşma, teşekkür, özür dileme, büyüklerden izin alma, selamlaşma, Ezan dinleme ve hapşırma vb. adablar şeklinde pratik olarak öğretilir. Örneğin, yemekten önce ve sonra ellerin yıkanması, yemeğe başlamadan ve yemekten sonra dua yapılması, tabağa yiyebileceği kadar yemek alınması, yemeğin sağ elle yenmesi, (sol elle yiyenlere sağ elle yemesi gerektiği, sağ elle yenirse sevap kazanılacağı öğretilir. Peygamberimiz (s.a.v.) gibi yapılmış olacağı anlatılır ve sol elde ısrar ederse zorlanmaz) ağızda yemek varken konuşulmaması gerektiği öğretilir. Yemeğe başlamadan önce yemek bittikten sonra yemek duası yapılır ve çocuklara neden Allah'a hamd edilmesi gerektiği anlatılır. Su içmeye besmele ile başlanması, su içtikten sonra da elhamdülillah denmesi gerektiği de öğretilir.

Çocuklara Ezan okunurken bir işle meşgul olunuyorsa bırakıp Ezanın dinlenmesi gerektiği mesela konuşuluyorsa susulması, müzik dinleniyorsa müziğin kapatılması gerektiği ve Ezan bitince ezan duasının okunması gerektiği anlatılır. Çocuklara şifahi olarak kısa süreler ve farklı dualar ezberletilir. Bu dualar öğretilirken, niçin dua edilmesi gerektiği ve duanın ruhunun gerekliliği de kavratılmaya çalışılır. Ayrıca çocukların dillerinin Besmele Elhamdülillah Sübhanellah Allahû Ekber gibi İslami terimlere alıştırılması amaçlanır.

Çocuk tarafından, çevresindekilerin Allah'a dua ederken bazı söz ve tavırlarının işitilmesi, görülmesi, onun bilincine yerleşir, taklit edilir ve yavaş yavaş benimsenir. Çocuğun söz ve tavırları henüz dinî konuları düşünüp anlama sonucu meydana gelmediğinden, onun davranışları mekanik olarak kendini gösterir (Peker, 1985, s. 24). Din eğitimi yapılacak kimseye önce bir takım dualar ve ibadet şekilleri tekrar tekrar gösterilerek öğretilmesi yöntemi yaygın olup $\mathrm{Bu}$ metot, doğal olarak dinin ilkel prensiplerini öğretmekte faydalı olmaktadır (Clark, 1981, s. 162). Okul öncesi çocuğuna kısa dualar, basit dini bilgiler oyunlarla, şarkılarla çocuğu sıkmadan öğretilebilir. Bu dönemde ahlaki eğitim, değer eğitimi ön planda tutulmalı, çocuğun ruhu dini pratikleri ve bilgileri özümsenmeye hazırlanmalıdır. Çocuğun inanç dünyasında duanın önemli bir yeri olması hasebiyle, ona özellikle anadilinde ve ezberleyebileceği uzunlukta bazı dua kalıplarının öğretilmesi, onda derin etkiler bırakacaktır (Karacoşkun, 2005, s. 124).

Okulun yanısıra aile de gereken manevi ortamın ve ibadetlerin sürdürülmesi, çocukların kimlik ve anlam arayışlarını desteklemekte ve aile içi ilişkilere olumlu yansımaktadır (Alpayadın vd. 2015, s. 66). Ancak çocuğun ibadetlere alıştırılması açısından oldukça ilgi ve sabır isteyen bu dönemde, katı ve baskıcı yöntemlerden, çocuğun dinden soğumasına neden olabileceği için uzak durulmalı ve onun henüz dini bir sorumluluk taşımadığı unutulmamalıdır. (Özdemir, 2002, s. 121).

\subsubsection{Günlük programı}

08.00-09.00 arası çocukların geliş saatidir. 09.00-09.10 eller yıkanır. 09.10-09.20 arası çocuklarla selamlaşılır ve çocuklara gün içerisinde yapılacak program anlatılır. 09.20-09.30 arası hazırlık yapılarak kahvaltıya geçilir. 09.30'da başlayan kahvaltı, 10.00'da sona erer. Kahvaltıdan sonra saat 12.00 'ye kadar çocukların fiziki ve ruhi gelişimleri için çeşitli pedagojik aktiviteler yapılır. Ahlak ve dil dersleri oyunlarla öğretilir. 12.00-12.30 arası öğle yemeği yenir ve çocuklar 13.30'a kadar dinlenirler. 13.30-15.00 arası pedagog ve öğretmenler gözetiminde çocuklara pedagojik çalışmalar yaptırılır veya hava durumuna bağlı olarak geziye götürülür. 15.00-15.30 arası ellerini yıkayan öğrenciler için Jause saati (Atıştırmalık saati)'dir. 15.30-17.00 serbest oyun ve eğlence saatidir. Saat17.00'de veliler çocuklarını anaokulundan almak zorundadırlar.

\subsection{Funkelstern (Özel Anaokulları)}

Türk girişimciler tarafından özel olarak açılan anaokullarına örnek olarak incelenen Funkelstern (Özel Anaokulları)'nı 1991 yılında Avusturya'ya gelen Mehmet Akkaya kurmuştur. 3 yıl meslek lisesi eğitimi aldıktan sonra 6 yıl mesleği ile alakalı ticaret işleriyle uğraşan Akkaya, daha sonra Avusturya'da 10 yıl market ve firın işletmiş, Türkiye'de de tekstil işi üzerine çalışmış Viyana'nın saygın işadamlarındandır. Kendisiyle yaptırılan röportajda bu okulları açma amacı ve okulların 
eğitimi üzerine bilgi alışverişinde bulunuldu. (Güner, 2017, s. 154-161). Bu görüşmeden elde edilen bilgilerin özeti aşağıda sunulmuştur.

\subsubsection{Kuruluşu ve Amacı}

2006 yılında bir Irak'lı işadamı ile iki grup oluşturarak kindergärten eğitimine başlayan Akkaya 2013 yılında toplamda 48 gruba ulaşmıştır. Hali hazırda Viyana'nın çeşitli bölgelerinde 7 kindergärten ile Funkelstern (Özel Anaokulları) eğitime devam etmektedir. Bu okullar sadece Müslüman çocuklarını değil diğer din mensubu çocuklarını da kabul etmektedir. Okulun kuruluşunun ana amacı hem o dönemde Müslümanlara hizmet veren kindergärten sayısının azlığı hem de Avusturya Devleti'nin kindergärten açılması için ciddi maddi destek vermesi gösterilmektedir. Bunun yanında, ilkokula başlayan çocukların Almanca konuşmada zorlanmaları, birçok ebeveynlerin her ikisinin de çalışıyor olması, diğer okullarda helal ve sağlıklı beslenmeye dikkat gösterilmemesi de okulların açılış amaçlarında belirtilmektedir.

\subsubsection{Veli Okul İşbirliği}

$\mathrm{Bu}$ anaokullarında, velileri eğitme amacıyla veli bilinçlendirme toplantıları ve seminerleri yapılmaktadır. Veli bilgilendirme toplantıları özellikle yeni okula başlayacak çocukların velileri ile yapılmaya özen gösterilmektedir. Aynı zamanda çocukların yeteneklerine göre, hangi okula gitmesi gerektiği konusunda da velilere yönlendirme ve bilgilendirme çalışmaları yürütülmektedir. Ancak velilerin sadece kindergärten eğitimine karşı değil, genel olarak zorunlu olan eğitime karşıda ilgisiz ve duyarsı oldukları belirtilmektedir.

\subsubsection{Pedagojik Çalış̧alar}

Eğitimde muhatapları iyi tanımak ve geleceğe daha iyi hazırlayabilmek için her çocuk hakkında bir data bank hazırlanarak, çocuklarla ilgili bütün gerekli bilgiler ve istatistikler toplanmaktadır. Çocuğun sosyalleşmesi, yani kendinin ve karşısındakinin de haklarına saygı, kendi sınırlarını bilmesi, (yerken, oynarken, konuşurken, uyurken) kendini koruması, paylaşmayı öğrenmesi okulun önemli prensiplerindendir. Önemli bir çalışma da üç yaş sonrası çocukların vücutlarını uyandırma ve enerji dengeleme programıdır. Normal bir çocuk 8 saat uyuması gerekirken bazı çocuklar, çeşitli nedenlerle bu kurala uyamayabiliyorlar. Buda doğal olarak çocuklar arasında bir dengesizlik oluşturuyor. Bazıları tembel kalırken bazıları ise çok hareketli olabiliyor, bu yüzden eğitime başlamadan önce 12 dakikalık belirli hareketler ve sportif faaliyetler yapılıyor ve bununla çocuğun algılamasını en üst seviyeye çekip tembel olanla hareketli olan aynı seviyeye getiriliyor. Bununla birlikte, Avusturya devletinin desteğiyle birlikte sağlıklı yaşam ve spor günleri programı dâhilinde, iki buçuk yaşındaki çocuklar için Viyana belediyesinden görevliler gelip, hava iyi ise dışarda hava kötüyse içerde çocuklara belirli egzersiz ve spor faaliyetleri yaptırmaktadırlar.

\subsubsection{Sosyal ve Kültürel Faaliyetler}

Okul eğitim koordinatörü başkanlığı bir ekip halinde, çocukların yaşlarına, dillerine, dinlerine ve kültürlerine uygun yıllık dış gezi planı hazırlamaktadır. Bu plana göre, Camiler, Kiliseler ve Avusturya'nın kültürel ve tarihi yerleri ziyaret ediliyor. Viyana ve Avusturya'daki hayvanat bahçeleri de ziyaret edilmektedir. Ayrıca üç yaş üstü çocuklara, Avusturya ve Türk kültürünü anlatan tiyatrolar seyrettirilmektedir. Bu tiyatro, gezi ve ziyaretler çocuklarda müthiş bir özgüven oluşmasını sağlıyor. Ziyaret edilen bu yerlerde anlatımlar, konu bütünlüğü açısından ve çocuğun hatırasında güzel izler bırakması açısından alanında uzman rehberler tarafından yapılmaktadır. Ayrıca çocukların anadillerini korumaları için, kendi anadillerinde kitaplar okunuyor ve eğitimciler dil dersleri veriyorlar. Bunun dışında haftalık anaokuluna en yakın oyun parklarına gidilmeye gayret edilmektedir.

Doğa eğitimine çok önem verilen okulda, dört yaşını geçmiş çocuklara perşembe günleri mutlaka şehrin ve ülkenin önemli yerlerini, doğal güzelliklerini anlatarak, çocukların değişik şeyler öğrenmesi sağlanmaktadır. Bazı meyve ve sebze bahçelerine gidilerek, ağacın nasıl dikildiği, nasıl sulandığ 1 , nasıl yetiştirildiği, örneğin elmanın, armudun veya bir sebzenin nasıl toplandığı, nasıl depolandığı, hem teknik açıdan anlatılmaya çalışılıyor hem de dinî açıdan üzerinde duruluyor. Yine çocuklara o günlerde tanıtılan meyve ve sebzelerden özellikle ikram edilmekte ve küçükte olsa evlerine götürmeleri için hediyeler hazırlanarak aileleri veya başkalarıyla paylaşma duygusu aşılanmaktadır. 


\subsubsection{Din eğitimi}

Okulda 2015 yılına kadar din eğitimi programı olmasına rağmen bu tarihte gelen yasaklama ile sadece kültürel ve ahlaki değerler anlatılabilmektedir. Ahlaki eğitimi gerçekleştirirken eğitmenlerin doğru kişi olmalarına çok önem verilmektedir. Bu nedenle eğitimcinin giyimi kuşamı konusunda, kültürümüze uyan standartlar getirilerek değerler ve ahlaki kurallar korunmaya gayret edilmektedir. Çocuklara iki dilde selamlaşma (Arapça ve Almanca) öğretilmektedir. Günlük ahlak ve görgü kuralları uygulanmaya gayret edilen okulda, farklı dinden ve kültürden çocukların gelmesi sebebiyle, yemekten önce yemek duası basit ve akılda kalıcı olması için tekerleme şeklinde yapılmaktadır. Yemeğin sonunda âmin ve elhamdülillah denilmektedir. Okulda dini bayramlar çeşitli aktivitelerle hem anlatılmaya hem kutlanmaya hem de yaşatılmaya gayret edilmektedir. Hristiyan çocuklara da kendi bayram ve dini günlerinde gerekli kutlamalar yaptırılmaktadır.

\subsubsection{Günlük programı}

07.00-09.00 arası okula gelen çocuklara, anaokulu eğitmenleri gözetimi altında serbest oyun imkânı verilir. Bütün çocuklar toplanınca, 09.00'da kahvaltıya geçilir. Çocuklar için bazı yemek ve kahvaltı kuralları mevcuttur. Buna göre, çocuklar önce sıraya girip ellerini yıkarlar daha sonra beraberce oturup hep birlikte yemeğe başlarlar. Beş yaşından itibaren çocuklar, sorumluluk gelişimine katkısı olması açısından, kendi tabak ve bardaklarını kendileri taşırlar. Yemeklere başlamadan önce mutlak suretle çocukların anlayabileceği oyun şeklinde Almanca dualar söylettirilir. Bu dua şu şekildedir. "Wir haben uns alle lieb, Gutenapetit"

Türkçesi: "Biz hepimiz birbirimizi seviyoruz, Afiyet olsun"

Yemekten sonra Almaca olarak mutlaka yerli dildeki Mahlzeit (afiyet olsun) geleneği ve kültürü çocuklara aşılanır. Yemekten sonra tekrar eller yıkanır. 09.30'da kahvaltı sona erer. Kahvaltıdan sonra 10.00'a kadar yarım saat, daire şeklinde oturularak, çocuk şarkıları söylenir, bu saatte gelmeyen öğrenciler tespit edilip not alınır, günün teması veya dersi ne ise oyunlarla beraber anlatılıp ögretilir. 10.00-11.30 arasında kâğıtlarla boyamalar, konsantrasyon arttırıcı oyunlar (kâğıdı şekilli kesme, boyama tekniği, yapıştırma, şekiller yapma ve fişler hazırlama gibi) oynamaları için çocuklar serbest bırakılır. Bu arada çocukların nasıl hareket ettikleri, arkadaşlarla iletişim kurma yetenekleri gözlemlenir. Zaman zaman çocuklarla beraber kitap okuma seansları yapılır, zaman zaman da çocukların hareket ve refleks kabiliyetini arttıracak ayakta çeşitli oyunlar oynanır. 11.30-12.00 arası çocukların yaratıcı fikirlerini ortaya çıkartma etkinlikleri yapılır. Bu etkinlikler yapılırken çeşitli oyuncak ve materyaller kullanılır, etkinlik bittikten sonra anaokulu öğretmenlerinin gözetiminde çocuklar bütün eşyaları kendileri toplayıp yerlerine yerleştirirler. 12.00-12.30 arası öğle yemeğinde de kahvaltıda olduğu gibi aynı süreç takip edilir ve çocuklara sağlıklı ve helal gıdalar sunulur. 12.45-14.15 arası çocukların grup halinde hareket etmeyi öğrenmeleri amacıyla küçük gruplar halinde oyunlar oynanır. Bu zaman dilimi içerisinde bir grup çocuk aktivitelerle meşgul iken diğer bir grup (ebeveynlerinin isteği üzerine) aynı oda içerisinde uyuyabilirler. Genellikler dört yaş ve altı çocuklar uyutulurken beş yaş ve üzeri çocuklar salı ve perşembe günleri ilkokula hazırlık dersleri görürler. 14.30-15.00 arası sağlıklı atıştırma vaktidir. Sunulan yiyeceklerden bazıları, meyve, sütlaç, yoğurt, meyve çayları, süt ve ekmek çeşitleridir. 15.00-15.30 arası çocuklara serbest oyun oynama izni verilir ve bu arada anaokulu eğitmenleri bir sonraki günün planını kararlaştırmaya başlarlar. 15.30-17.00 arası çocuklarla hareketli faaliyetlerde bulunulur, çocuklara hikâyeler okunur. Aynı zaman zarfı içerisinde veliler çocuklarını almaya gelmeye başlamış olur.

\subsection{Isma Kindergarten}

Isma Avusturyalı Müslümanların kurmuş olduğu bir okuldur. Anaokulları ve okullar projesinin ilk temelleri Avusturyalı Müslümanlar tarafından, 2008 yılında atılmış olup, ISMA ve IKRA adında anaokulları ve başka isimler altında ortaokul ve liseliler açmışlardır. Isma anaokulu müdiresi ile yaptırılan röportajda (Güner, 2017, s. 154-168) bu tür okulları açmaya yönelmelerinin amacını da içeren, kendi yaşadığı sıkıntıları şu şekilde anlatmıştır:

Benim iki çocuğum bundan önce Avusturya anaokullarına gittiler, Avusturyalı olmama rağmen çocuklarım kendilerini orada yabancı gibi hissettiler, çok pahalı ve özel bir anaokulu olmasına rağmen çocuğumun ne yemeği ile ne de eğitimiyle gerektiği gibi ilgilenmediler ve Hristiyan adet ve kültürünü adeta dikte etmeye çalıştılar. Birçok Hristiyan örf, adet ve geleneklerini çocuklarımın bilinçaltına yerleştirmeye çalıştılar. Bu yüzden bunları yaşayan birisi olarak, bizim anaokullarımızın ne manaya geldiğini daha iyi anlayabiliyorum.

11 | $\mathrm{P}$ a g e

www.iiste.org 
Müdirenin bu ifadelerinde de görüldüğü üzere, Avusturyalı Müslümanlar, çocuklarını Hristiyan adet, gelenek, görenek, dini gün ve geceleri uzak tutmak, İslami geleneklere sarılmalarını sağlamak, haram gıdadan uzak tutmak ve ögretmenlerinin gelecekteki davranışlarını etkileyecek hal hareket ve uygunsuz giyinme sorunlarını kaldırmak gibi sebeplerle kendi okullarını açmaya mecbur kalmışlardır.

\subsubsection{Dil eğitimi}

Avusturyalı Müslümanlar tarafından açılan bu okullarda farklı dillere sahip Müslüman çocuklar da eğitim almaktadır. Bu nedenle farklı dillere sahip çocuklara anaokulunun son senesinde dil testi yapılır. Yeterli olmayanlara özel destek kursu sağlanır. Dil konusunda çocukların yaşlarına uygun hikâye ve edebiyat kitapları okunmasına gayret edilir, hatta kitaplar çocuklara ailelerinin kendilerine okutulması için eve de emanet gönderilir. Yine aynı şekilde çocukların ana dilinde hikâye kitapları okunarak ana dillerinde de geliştirilmeleri sağlanmaktadır.

\subsection{2. Özel Günler ve Bayramlar}

2015 yılında Avusturya'da ortaya çıkan İslami anaokulu krizinden sonra bütün anaokullarında, Hz. İsa'nın doğumu (Weinachten), Yılbaşı (silvester), Yumurta bayramı (Ostern Feriern), Karfreitag (Hz.İsa'nın çarmığa gerilmesi) vb. Hristiyan bayram gün ve gecelerini kutlama ve benimsetme zorunluğu getirilmiştir. Bununla birlikte İslami gün ve geceler öncesi veya sonrası mutlak suretle kutlamalar yapılmaktadır. Örneğin, Hac günlerinde çocuklara ihram hazırlanıp ortaya bir Kâbe maketi konup sembolik bir Hac ibadeti yapılması hem çocuklar, hem de aileler açısından yaşanmışlık hissi vermektedir. Ayrıca o gün için hediyeler hazırlanmakta, çocukları hem zihin açısından geliştirmek amacıyla hem de dini günlerimizin önemi kavratmak amacıyla boyama ve el işleri yapılıp çeşitli oyunlar oynatılmaktadır. Ramazan bayramında da çeşitli kutlamalar yapılmaktadır. Böylece, Hristiyanlık ve İslami dini günler dengeli olarak verilmeye ve öğretilmeye çalışılmaktadır.

\subsubsection{Ahlâk eğitimi}

Okulda daha çok, büyüklere saygı, ruh, beden ve çevre temizliği, dayanışma, grup içinde uyumlu yaşama bilinci, asla yalan söylememe, kavga ve dövüş etmeme, yemeklerden önce ve sonra temizlik, yemeklerden önce ve sonra dua ve şükür, sofrayı birlikte hazırlayıp kaldırma gibi ahlâkî prensipler öğretilmektedir. Yine dinimizdeki önemli şahsiyetler çocukların anlayabileceği şekilde hikâye tarzında anlatılmaktadır.

\subsubsection{Günlük programı}

07.00-08.00 arası okula gelen anne ve çocuklar selamlanır ve çocuklar serbest oyun oynarlar. Fakat bu erken saatte genelde çalışan veliler çocuklarını getirirler, diğer çocuklar ise 09.00'a kadar gelmiş olurlar ve asıl program o zaman başlar. 8.30- 9.30 arası gelen çocuklar ellerini yıkadıktan sonra, anaokulu eğitmeni gözetimi altında, açık büfe de bulunan kahvaltı seçeneklerinden kendilerinin istediklerini alıp dua ile başlayarak kahvaltılarını yaparlar. Kahvaltı yapmak istemeyen çocuklar da oyun alanında zaman geçirirler. Pedagog ve çocuklar için en değerli vakit olan 09.30-10.00 arası, şiirler şarkılar söylenerek çeşitli aktiviteler yapılır. Daha sonra 10.40'a kadar çocuklar tek başlarına, serbest boyama çalışmaları, yazılı ve geliştirici bulmacalar, hamur oyuncaklarından ve kumdan şekiller yaparlar. 10.40-11.30 arası maksimum 5 kişilik küçük gruplar halinde hikâyeler okunur, el işi örnekleri uygulamaları yapılır veya bahçede beden eğitimi dersi yapılarak çeşitli fiziksel aktiviteler yerine getirilir. 11.30'dan 12.15'e kadar çocuklar yemek masasını hazırlarlar, ellerini yıkadıktan sonra herkes yemeğini kendisi alır. Çocuklar yemekten aldığı kadarını yemek zorundadır. Yemekten sonra da herkes kendi tabağını ve bardağını kaldırır.

12.15-14.00 arası yemekten sonra dört yaşından küçük çocuklar bir müddet uyurlar, uyumayan çocuklar serbest oyun oynarlar. Bunun yanında özel takviyeye ihtiyacı olan çocuklara ekstra Almanca ve zekâ geliştirici çalışmalar yaptırılır. 14.00-14.30 arası küçük atıştırma vaktidir çocuklar burada meyve sebze ve küçük, sağlıklı atıştırmalıklar yerler. 14.30-15.00 arası çocukların bir kısmı gitmiş olur kalan çocuklarla ruh halleri sakinse dikkat oyunları oynanır. Eğer yaramazlıkları varsa müzikli ve sesli oyunlar oynanır. Bu çocukların ruh hallerine göre karar verilen bir durumdur. 15.00-16.00 arası tekrar bahçeye çıkılır veya civardaki çocuk parklarından birine gidilir. 16.0017.00 arası bütün gruplarda bir kaç çocuk kalmıştır hepsi bir araya toplanır veliler gelene kadar serbest oyun oynanmasina izin verilir.

12 | P a g e

www.iiste.org 


\subsection{Kindergarten Lernen fürs Leben}

Bu okul Avusturyalı Müslümanların açmış olduğu diğer farklı bir kurumun anaokuludur. Viyana'da iki şubesi bulunmaktadır. Avusturyalı Müslümanlar tarafın çok rağbet gören bir eğitim kurumu olması nedeniyle, çocuğunu bu anaokuluna kaydetmek isteyen veliler en az iki sene öncesinden ön kayıt yaptırmak mecburiyetindedirler. "Lernen fürs Leben" anaokulları gerçekten kaliteli bir dil eğitimi, kaliteli bir din eğitimi ve çocukların karakter ve kişiliklerini geliştirici bir eğitim vermektedir. Hatta bu anaokulunu giden çocuklar okula başlama çağına geldiğinde, birçok resmi ve özel okullar bu anaokulundan geldiğini beyan ve ispat eden velilerin çocuklarını sınava tabi tutmadan kayit etmektedirler.

Yukarıda bahsi geçen ve ziyaret edilen anaokullarında uygulanan programların çoğu birbirine yakın programlardır. $\mathrm{Bu}$ anaokulundaki farklılık ise Misır asıllı bir hoca hanım tarafindan uygulanmaktadır. Hoca hanım 5 kişilik bir grubu 40 dakika derse alıyor bunlara şifahi üslupla Duha süresinden Nas süresine kadar kısa sureleri ve buna ek olarak birçok Hadisi ezberletiyor. Bunları ezberletirken çocukların bu işi severek ve isteyerek yaptıklarını müşahede ediyorsunuz. Ezberletilen hadisler Almanca, Arapça ve Türkçe olarak bir dosya halinde, ezberlenen süreler ise liste halinde evde takibi yapılabilmesi için velilere verilmektedir. Çocukların bu ezberleme işini sevmeleri ve çocukları bu işe özendirmek için okulun duvarına bir liste asılmıştır ve her ezberleyen çocuk bu ezbere mukabil bir adet başarı etiketi alıp o listeye yapıştırmaktadır. Bunun dışında çocuklara birçok Arapça dua öğretilmekte, güzel ve sağlam İslami alt yapı verilmeye gayret edilmektedir.

\subsubsection{Günlük Programı}

07.00-08.00 arası işe erken giden anne babaların çocuklarını bırakmaları için anaokulu açılır. Gelen çocuklara küçük bir kahvaltı hazırlanır. 08.00-09.00 arası çocukların anaokuluna gelme saatidir ve genelde saat 08.30 'da bütün çocuklar gelmiş olurlar. 08.30'da yoklama yapıldıktan sonra kahvaltı başlar. Çocuklar kahvaltı tabaklarını kendileri hazırlarlar. Çocuklara kahvaltıda yiyebilecekleri kadar yemek almaları öğütlenir. Yemeğe besmele ile başlanır. Yemekten önce ve sonra dua yapılır. Kahvaltıdan sonra her çocuk tabaklarını kendisi mutfağa götürür. 09.00-09.30 arası çocuklar için serbest oyun saatidir. 09.30-10.00 saatleri arasında çocuklarla sabah halkası yapılır ve o günkü program açıklanır. 10.00'dan sonra yarım saat çocuklar serbest oyun oynarlar. 10.30-11.00 arası büyük grup için Kur'an dersi saatidir. 11.00'den sonra yine kırk dakika çocuklar serbest oyun oynarlar. 11.40-12.15 arası öğle yemeği vaktidir. Çocuklara sorumluluk bilinci aşılamak amacıyla, her çocuğa kendi tabağını aldıktan sonra yiyebileceği kadar yemek alması istenir. Çocuklar tabaklarındaki yemeklerini bitirir ve tabaklarını mutfağa götürüp aşçıya teslim ederler. Su içme alışkanlığı kazandırmak için her grubun ve her çocuğun kendine ait bardağ 1 vardır. Su köşesinde sürahi ve bardaklar bulunur. Herkes kendi bardağını kullanır. Kimse kimsenin bardağını kullanamaz. Bardağı herkes kendi doldurup besmele çekerek içer. Büyük olanlar küçük olanlara yardım ederler. İçtikten sonra elhamdülillah derler.

12.15-14.00 arası küçük grup için uyku saatidir. Uyumak istemeyenler uyuyan arkadaşlarını rahatsız etmemek şartıyla oyun oynayabilirler. Yaşları nispeten büyük olanlar Kur'an dersine geçerler. 14.00-14.30 arası atıştırmalık saatidir. 14.30-15.00 arası o gün için hazırlanan öğle programı uygulanır. 15.00'ten sonra yarım saat çocuklar serbest oyun oynarlar. Eğer hava durumu uygun olursa parka gidilir veya okul bahçesine çıkılır. 16.00-17.30 arası veliler çocuklarını okuldan alirlar.

\section{Müslümanların Kurduğu Yaygın Anaokulları}

Avusturya'da örgün eğitiminin dışında yaygın olarak eğitim veren birçok cami, dernek ve kuruluş yaygın olarak çocuklara hafta sonları iki gün olarak (Cumartesi-Pazar) okulöncesi din eğitimi vermektedir. Bu okullardan örneklik teşkil etmesi açısından farklı STK'lara bağlı dört anaokulu incelendi. Bunlar IFW'ye (Viyana İslam Federasyonu) bağlı Mektep Eğitim Kurumları'ndan Viyana'nın 20. Bölgesindeki Mektep-20; Wonder (Viyana İmam Hatipliler Derneği)'ne bağlı "Kubbe 6 Çocuk Kulübü”, T.C. Diyanet İşleri Başkanlığı'na bağlı camileri ifade eden ATIB Union (Avusturya Türk İslam Birliği)'ne bağlı anaokulları Kardeşlik Derneği’ne bağlı anaokullarıdır. İncelenen bu okullar sırasıyla aşağıda verilmiştir.

\subsection{Mektep-20}

IGMG (Islamische Gemeinschaft Millî Görüş / İslam Toplumu Millî Görüş)'e bağlı IFW (Islamische Föderation in Wien / Viyana İslâm Federasyonu) bünyesinde Viyana ve Viyana

13 | P a g e

www.iiste.org 
çevresinde beş tanesinin adı Mektep olmak üzere 15 eğitim merkezi bulunmaktadır. Hafta sonu 3 6 yaş arası eğitim veren bu kurumlarda yapılan eğitimin tamamı IGMG'nin belirlemiş olduğu temel eğitim müfredatına göre yapılmakta ve yine IGMG'nin hazırlamış olduğu eğitim materyalleri kullanılmaktadır. İncelenen "Mektep 20" de bu eğitim kurumlarından biridir.

"Mektep 20" 20. Viyana' da bulunan, Rıdvan Cami bünyesinde kurulan bir eğitim kurumudur. Diğer camilerde olduğu gibi, Rıdvan Camisinde de yıllarca cami mantığ 1 ile yani 80-90 öğrenciye bir hoca ile eğitim yapılırken, IFW'ye bağlı tüm eğitim kurumlarında kurumsallaşma ve eğitim kalitesini artırma amaciyla değişikliğe gidilmiştir. "Mektep 20" de bu değişiklik neticesinde 2008'den itibaren Anasınıfi-1 ve Anasınıf1-2 olmak üzere her eğitim ve öğretim yılında iki sınıf öğrenciye (toplam 40 öğrenciye) eğitim verilmektedir. Bu yaş grubu Viyana'da yaşayan Türk ve Müslüman ailelerin çok rağbet ettiği bir yaş grubu olup kayıtlar bir iki yıl öncesinden dolmakta ve birçok çocuk yer sıkıntısı yüzünden geri çevrilmektedir. Ayrıca “Mektep-20” eğitim merkezinde bahsedilen bu iki anaokulu sınıfı da dâhil olmak üzere toplam 13 sınıfta 3-14 yaş arası 260 öğrenci hafta sonu eğitimi almaktadır.

\subsection{Müfredat ve Ders Materyalleri}

"Mektep 20" Anasınıflarında IGMG'nin hazırlamış olduğu ve kuruluşa bağlı Avrupa'daki tüm Cami ana sınıflarında geçerli olan eğitim müfredatı uygulanmaktadır. Eğitim programlarına uygun olarak kitap hazırlıkları da yapılmıştır. 3-6 yaş öğrenciler için "Minikler İçin Temel Dini Bilgiler Öğretmen El Kitabı”, "Elif-Ba Boyama Kitabı”, 3, 4 ve 5 yaşındaki çocuklar için ayrı ayrı çocuk boyama kitapları, “On Parmağım Marifetli Ellerim” kitapları hazırlanmıştır. Ayrıca "Arkadaş Arayan Elif", "Ahmet'in Kurban Bayramı Sevinci”, "Karlı Bir Park Macerası", "Hikmet Dededen Sohbetler" gibi farklı kitaplar basılmıştır. Bu dönem çocuklarının sınıf ortamında kullanabilecekleri "Namaz Öğreniyorum”, “Abdest Alıyorum", "Cami Adabı”, "Elif -Beliler Ailesi” gibi afişler de basılmıștır.

Bununla birlikte bazı konularda internetten veya farklı kitaplardan destek alınmaktadır. Temel Bilgiler, Kur'an-1 Kerim ve Esma-ül Hüsna'yı ezberleme dersleri yapılmaktadır. Kurum prensibi olarak, çocukların yaşları hasebiyle Kur'an'a erken geçmeleri istenmese de gayretli olan öğrenciler için istisnalar uygulanmaktadır. Öğrencilere teşvik amaçlı Kısa sureler, Esma-ul Hüsna yarışması ve bilgi yarışması gibi çeşitli etkinlikler de düzenlenmektedir.

\section{3. Öğretilen Konular}

Özellikle ağırlıklı olarak birinci yıldan başlamak üzere çocuklara şu değerler verilmeye çalışılmaktadır. Tanışma Adabı: Ben kimim? Sen kimsin? İsimli bir oyun oynanır. İple oynanan bu oyunda herkes kendini tanıtır ve ucunu tuttuğu yumağı tanımak istediği kişiye atar. Daha sonra herkes yanındakinin ismini hatırlamaya çalışır. Selamlaşma Adabı: "Her dilde selamlaşmak" kukla oyunu olarak işlenir, ayrıca çocuklar kendileri selam vermeyi ve almayı öğrenirler. Misafirlik Adabı: Misafire nasıl davranılacağı ve misafirlikte nasıl davranılacağı tiyatro şeklinde oynanır. Doğru ve yanlış hareketler üzerinde konuşulur ve sonrasında boyama yapılır. Temizlik Adabı: Önemli olan bazı temizlik malzemeleri tanıtılır ve bunların beden temizliğinde nasıl kullanılabilecekleri işlenir. "Temizlik imanın yarısıdır” Hadisi öğrenilir ve temizlik kartları yapılır. Besmele: "Besmele Şiiri” dinletilir ve el becerisi ile her işe başlarken Besmele çekilmesi gerektiği öğretilir. Yemek Adabı: Yemekten önce Bismillah, sonrasında Elhamdülillah denilmesi gerektiği öğrenilir.

İslam Kardeşliği: İslam’ın bütün dünyadaki Müslümanları bir araya getirdiği öğrenilir ve konuya uygun bir boyama yapılır. Kutlu Doğum: Peygamberimiz'in doğumu kutlanır ve kabri olan yeşil kubbenin resmi boyanıp kart yapılır. Mevlid Kandili: Mevlit Kandili hakkında konuşulur ve kandil kartı yapılır. Kurban Bayramı: Kurbanlık hayvanları tanıtılır ve duvar afişi yapılır. Ayrıca Kurban Bayramı kartları hazırlanır. Kurban Bayramı kutlaması yapılır ve hocalarla önceden hazırlanmış hediyeler verilir. Hediyeleşme ahlakı çocuklarda yerleştirilmeye çalışılır.

İnanç konularında bilgiler verilir. Allah Yaratandır: Allah’ın birliği öğrenilir ve boyama yapılır. Dört Büyük Melek: Dört Büyük Melek'in görevleri öğrenilir ve bir oyunla adları akılda tutulmaya çalışılır. Hz. Yunus: Hz. Yunus çizgi filminden kesintilerle Peygamberin hayatı tanıtılır ve ardından el becerisi ile Hz. Yunus’un balığın karnına düştüğü anı canlandırılır. Dört Büyük Kitap: Dört büyük kitabın verilmiş olduğu peygamberlerin isimleri ile kitapların adları çocuklara akıllarında tutabilmeleri için bir şarkı şeklinde öğretilir. İlk İnsan Hz. Âdem: Peygamber Efendimiz dışında başka peygamberlerin de olduğu öğrenilir, ilk insanı ve eşini tanıdıktan sonra boyama yapılır. Hz.

14 | $P$ a g e

www.iiste.org 
Nuh ve Tufanı: Bir çizgi filimden karelerle Hz. Nuh anlatılır ve O’nun yapmış olduğu gibi küçük gemiler yapılıp içlerine çeşitli hayvanlar bindirilir (el becerisi). Ayrıca Aşure Günü için kâğıtlara çeşitli malzemelerle aşure yapılır (el becerisi). Aşçının yapmış olduğu aşure yenilir. Güzel Peygamberim: Peygamberimiz tanitılır.

İslam'ın beş şartı sırasıyla öğrenilir. Abdest almayı biliyorum: Abdest alma öğretilir, çeşitli abdest kartları ve boyamaları yapılır. Namaz için gerekli olan malzemeler öğrenilir ve Namaz istasyonları adı altında bir döngü yapılır. Bu aktivitede çeşitli istasyonlarda namaza hazırlık yapılır. Bir istasyonda abdest alınır, bir istasyonda ezan dinlendirilir, bir istasyonda tesbih çekilir, bir başka istasyonda dua ile alakalı bir resim boyanır. Ayrıca çocukların görevlerini tamamlayabilmeleri için her gittikleri istasyonda işlemi bitiren çocuğa bir çıkartma verilir. Dört çıkartma alan öğrencinin görevi biter ve namaza hazır bir şekilde bekleyebilir. Cennetin Anahtarı Namaz: Power Point gösterisi yapılır ve toplu namaz kılınır. Oruç: Ramazan ayı içerisinde önemli olan sahur, iftar, hurma ve Ramazan Bayramı gibi önemli kelimeleri öğrenilir. Zekât vermek: "Komşusu açken tok yatan bizden değildir" Hadisi öğrenilir. Kâbe maketleri ile hac canlandırılması yapılır. Peygamberimize Hediye: Umreye gidecek olanlara Peygamberimiz için hazırlanan resimler teslim edilir ve resimler Medine'ye gönderilir.

Meslekleri tanıyalım: Öğrencilerin hayallerindeki meslekleri tanıtılır. Sonrasında bu mesleklere uygun resimleri boyanır. Sonbahar: Yaprak toplamaya gidilir ve toplanan yapraklardan el becerisi ile Sonbahar canlandırması yapılır. Hz. Osman çizgi filminden konuya uygun bir kısa izlenilir ve sonrasında film hakkında konuşulur. Konuyu daha iyi anlamak için el becerisi yapılır.

\subsection{Günlük Ders Akışı}

Aileler çocuklarını her gün ders başlamadan on beş dakika önce teslim ederler. Çocuklar sokak (dışarı) ayakkabılarını çıkarıp terliklerini giydikten sonra sınıflarına girerler, hocalarına selam verip yerlerine geçerler. İlk önce çocuklara haftalarının nasıl geçtiği sorulur ve hasbihal edilir. Ders saati gelince derse besmele ve Rabbi Yessir duası ile başlanır. Hocalar gruplara ayrıldıktan sonra dersler dinlenmeye başlanır ve ezberleri alınır. Bazı günler toplu bir şekilde mahreç çalışması yapılır. Kahvaltıya kadar Elif-Ba dersi tamamlanır ve sırayla eller yıkanır ve kahvaltıya geçilir. Hep beraber yemeğe başlama duası yapılıp, besmele çekip aynı anda yemeye başlanır. Kahvaltıdan sonra masalar çocuklar tarafindan toplanır.

Çocuklara kahvaltı esnasında yemeğin tadı, kokusu, nasıl yapıldığı ve kimin yarattığ sorulur. Böylelikle çocuklara hem tefekkür etme hem de yemek adabı ve alışkanlığı kazandırılmış olur. Tabaktaki yiyeceklerini bitirmeleri ve yemek israf etmenin (bitirmemenin) ne olduğu anlatılır. Sofradan hep beraber kalkılır. Yemeğin sonunda toplu bir şekilde yemek duası yapılır ve her çocuk tabağını mutfağa kendisi götürür. Ardından eller yıkanır ve teneffüs yapılır. Teneffüs bittikten sonra hoca çocukları ikinci derse toplar. Müfredata göre konu anlatımı yapılır ardından konu hakkında etkinlik, el becerisi, boyama, soru-cevap, yarışma, vs. yapılır. Boyama aktivitesinde çocuklara önemli İslami şahsiyetleri ve kutsal mekânları boyayarak öğretme amaçlanır. Dersin bitimine doğru cemaat ile öğle namazı kılınır. Bazı günlerde toplu bir şekilde dualar, sureler veya Esma-ül Hüsna tekrarlanır. Bazen de oyun oynatarak ders sonlandırılır ve çocuklar ailelerine teslim edilir.

\section{Kubbe 6 Çocuk Kulübü}

Kubbe 6 Çocuk Kulübü, 2007 yılında Wonder (Viyana İmam Hatipliler Derneği) bünyesinde Viyana'da başlayan ve hedef kitlesi Viyana'da yaşayan Türk ailelerin 4-11 yaş arası çocukları olan bir projedir. Bu proje kapsamında hafta sonları dokuz saat olmak üzere dinî ve kültürel eğitim verilmektedir. Eğitim dönemi ekim ayından haziran sonuna kadardır. Okul öncesi sınıflarında yaş sınırı 4-5 olarak belirlenmiştir. Eğitim saatlerinde bir de pedagog hazır bulunmaktadır. Bu şekilde öğretmenlerin ve velilerin çocukların problemleri hakkında danışabileceği ve sağlıklı çözümler bulabileceği bir ortam hazırlanır.

\subsection{Müfredat ve Ders Materyalleri}

Müfredat, boyayarak ve drama uygulayarak öğrenme üzerine hazırlanmıştır. Kur'an-1 Kerim dersinde harf boyama kitapları üzerinden ve çeşitli materyallerle ilk iki ay içerisinde hafta sonu yapılan derslerde yalnızca harfler üzerinde durulur. Sonraki süreçte harf kitabından cüze geçilir. Böylelikle Kur'an okumayı öğrenme süresi hızlandırılır. Ezber dersinde öncelikle "Yemek Duası" gibi çocukların günlük hayatta kullanabilecekleri dualar öğretilir. Dualar sınıf içerisinde birlikte 
tekrar edilerek öğrenilir. Ahlak Dersleri değerler eğitimini içerir. Bu derslerle günlük hayatta dikkat edilmesi gereken ahlaki değerlerin öğretilmesi hedeflenir. Konular dramatize edilerek anlatılır. Türkçe derslerinin amacı, gurbetçi ailelerin çocuklarına doğru Türkçe konuşmayı ve Türkçeyi anlamayı öğretmektir. Okul öncesi sınıflarda Ahlak dersleri ile birlikte işlenen Türkçe derslerinde, anlatım bozuklukları düzeltilir. Dinleyip, anladığını anlatma üzerine pratikler yapılır. İslam Tarihi’nde Peygamberimizin hayatı şiirler, ilahiler ile desteklenerek öğretilir. Boyama kitabından konuyla ilgili bölümler ders sırasında boyanır. İbadet derslerinde Allah, Din, Peygamber, Melek gibi dinî terimler okul öncesi seviyesine uygun çalışmalarla anlatılır. İbadet esasları uygulamalı işlenir. Tüm derslerle ilgili evlere sorumluluk ödevleri yanında, her gün akşam namazını kılmak, eve girerken selam vermek, yatağını toplamak vb. pratikler de sorumluluk gelişimi açısından velilere takip ettirilir. Ayrıca her hafta bir sorumluluk kahramanı seçilir.

\subsection{Günlük Ders Akıșı}

Hafta sonu Cumartesi günleri dersler saat 10.00'da başlar ve 15.00'e kadar devam eder. Pazar günleri ise 13.30'a kadar devam eder. Cumartesi günleri 3. ders sonunda öğle namazı kılınır ve yemek yenilir. Sonrasında ise Aktivite saati başlar. Aktivite Saat'inde tiyatro, koro, ebru sanatı, satranç, tekwando, futbol gibi aktiviteler çocukların tercihlerine göre belirlenir. Her öğrenci kendi aktivitesini ilk iki haftada seçmek zorundadır. Sonrasında değişim, ancak öğretmenin talebiyle mümkün olur. Bu aktiviteler ayda iki defa yapılır. Diğer iki haftadan birinde Aktivite Saat'inde film izlenir, diğerinde ise gezi düzenlenir. Geziler, Avusturya'nın kültür mirasını tanımaya yönelik programları içerir. Gezilerde özellikle kılavuz alternatifi sunan kurumlar tercih edilir.

Pazar günü ise 3. dersin sonunda öğle namazının ardından öğrenciler, ailelerine teslim edilir. Dersler özellikle Türkçe yapılmaktadır. Çocukların anadili olan Türkçeyi doğru öğrenmeleri temel gayelerden biridir. Okuma, yazma, konuşma, anlama çalışmaları yoğun bir şekilde yapılır. Her öğrenci çantasında katılım defteri bulundurmak zorundadır. Bu katılım defterine öğretmen öğrencinin ödevleri sorumlulukları ve son durumu ile ilgili bilgilendirmeler yazar. Bir sonraki hafta defter veli tarafindan imzalanarak gönderilir. Aktivite derslerinde yapılan çalışmalar, sene içindeki Kutlu Doğum Haftası, Karne şenlikleri gibi müsamerelerde sergilenir.

\section{ATİB Union (Avusturya Türk İslam Birliği)'ne Bağlı Anaokulları}

Türkiye Diyanet İşleri Başkanlığına bağlı cami derneklerinin çatı kuruluşu olan ATİB (Avusturya Türk İslam Birliği), Avusturya'da yaşayan Müslümanların dinî ve eğitim vecibelerini yerine getirmek üzere 1990 yılında kurulmuştur. ATİB Avrupa'da, Türkiye'de Diyanet İşleri Başkanlığı tarafından, 2012 yılında tamamlanan ve 2014 yılında başlatılan ciddi bir proje ve çalışmayla anaokulu eğitim çalışmalarına 2015-2016 eğitim ve öğretim yılında başlamış ve Viyana pilot bölge seçilmiştir. $\mathrm{Bu}$ anaokullarında bizzat derslere katılarak yaptırılan gözlemlemeler neticesinde şu bilgiler edinilmiştir. (Güner, 2017, s. 180-182).

İlk derste, kültürümüzde ve Türkiye'de çok yaygın olan Hacivat'la Karagöz aracılığıyla çocuklara Peygamber Efendimiz'in hayatından bir bölüm drama yöntemi ile anlatılmıştır. Din eğitiminde önemli metotlardan biri olan bu yöntem sayesinde çocukların zihinsel, duygusal ve psikomotor deneyimlerinin ortak çalışması amaçlanmıştır. Anlatım esnasında Hacivat ve Karagöz birbirlerine sorular soruyor ama cevaplar çocuklardan beklenmiştir. Çocuklar dinlerken ve sorulara cevap verirken dikkatleri hem anlatılanlara çekiliyor hem de keyif aldıkları gözlemlenmiştir. Oyun bittikten sonra anlatılanlar veya Hacivat ve Karagöz’ün diyalogu sorular şeklinde eğitmen ve çocuklar arasında devam etmiş konu üzerine çocukların yorumu alınmıştır.

İkinci derste bizzat canlı müzik eşliğinde birinci dersi destekler mahiyette 571 ilahisi söylenmiştir. Daha sonra Peygamberimiz'in hayatı bir oyunla anlatılmaya devam edilmiştir. Oyunda çocuklar doğru bilirlerse güller açıyor, yanlış cevap da ise güller kapanıyor veya soluyordu. Örneğin eğitmen Peygamberimiz (s.a.v.)'in doğum tarihini 615 olarak söyleyince, çocukların birçoğu hemen yere çöküp, ellerini aşağı doğru açarak gülü solduruyor. Peygamberimiz'in eşi Hatice midir? Diye sorunca, güller açıyor çocuklar ellerini yukarıya doğru kaldırıyorlar. Çocukları zinde ve dersin içinde devamlı tutmak için "onu görmek için neler neler vermezdim” isimli başka bir ilahiye geçiliyor. İlahi söylenirken çocuklar serbest birakılıyor hem sözlü hem de hareketlerle ilahiye katılımları sağlanıyor. Çocuklar biraz serbest oynadıktan sonra eğitimcinin daha önce hazırlamış olduğu boyama dersine geçiliyor. Boyama kâğıdında, günün önemine ve derslere uygun bir şekilde hazırlanan gül ve gülün ortasında Arapça Muhammed yazısı var. Çocuklar gönüllerince farklı renklerde boyayıp gerçekten çok güzel el işleri ortaya çıkarıyorlar. Eğitmen bir ders içinde bu kadar

16 | P a g e

www.iiste.org 
hızlı değişiklik yapmalarının sebebini, bu yaştaki çocuğun katılımı ve konsantrasyonun beş dakika olması şeklinde ifade etmiştir.

Kur'an eğitiminde ise harflerin tanıtımı yapılıyor. Kur'an-1 Kerim harfleri, boyama, oyun kâğıtlarıyla yarışma, hamurla yazma gibi değişik şekillerde çocukların benliğine yazılmaya çalışılıyor. Eğitimci bu yaşın amacının tamamen değerler eğitimi olduğunu söylüyor ve dersin sonuna doğru hep bir ağızdan kısa sureler, yemek duası, vitir duası, derse başlama duası yani "Rabbi Yessir velâ tuassir" duası söyleniyor. Eğitmen, anaokulu eğitiminin amaçlarından birisinin de çocuğu gözlemleyip hangi alanda başarılı olduğunu tespit etmek olduğunu ifade etmiştir. Eğitimcinin iyi ve ciddi bir gözlemleme ve ilgiden sonra sınıfından hafizlar, doktorlar, öğretmenler ve mühendisler çıkacağına inancının tam olduğu görülmüştür. Aynı eğitim merkezinde başarılı çocukların hafızlığa yönlendirildikleri de görülmüştür. Metaryal seçiminde hem klasik hem de dünyada bugün kullanılan modern eğitim eşyalarını seçmeye özen göstermektedirler.

\section{Kardeşlik Derneği’ne Bağlı Anaokulları}

2012 yılının Ekim ayında faaliyetine başlayan Kardeşlik Derneği bünyesinde, anaokulları yanında, İslam Araştırmaları Enstitüsü, Arifan Kütüphanesi, Gülzar-1 İrfan Hafızlık Kursu, Genç Akademi, hafta sonları ilk ve ortaöğretim çocuklarına Temel Dini Dersler Kursunu barındırmaktadır. Dernek bütün bu kurumlarda toplam 37 eğitimci ve 341 öğrenci ile eğitim, öğretim ve uygulama faaliyetlerini sürdürmektedir. Müfredatı, Türkiye'deki Kur'an Kursları, İmam Hatip Liseleri ve İlahiyat Fakülteleri programları dikkate alınarak hazırlanmıştır. Ayrıca Türkiye'den birçok önemli akademisyeni de davet ederek ders verdirmektedir. Özel derneklere ait anaokullarına örnek teşkil etmesi için incelenen Kardeşlik Derneği'ne bağlı hafta sonu kurslarında 24 farklı sınıf mevcuttur. $\mathrm{Bu}$ sınıflardan dördü 4-6 yaş anaokulu öğrencilerine aittir. 4-5 ve 5-6 yaş aralıklarında gruplandırılmış bu ana sınıflarında ikişer eğitmen bulunmaktadır. Dersler Cumartesi ve Pazar günleri dörder saat olup, çocuklar oyunla eğitilmektedir. Müfredatların tamamı uzman komisyonlar tarafından hazırlanmakta ve bu müfredat hazırlanırken birçok din eğitimcisi ve hocaların görüşlerinden istifade edilmektedir.

\subsection{Günlük Ders Akışı}

Saat 9:05'te sınıflarında toplanan çocuklar, selamlaşmanın ardından yuvarlak halka olup Euzubesmele çekerek derse başlarlar. Dersin başlangıcında, Rabbiyessir duası ve Fatiha Suresi manalarıyla birlikte okunur. Çocuklara günlük programla ilgili bilgiler verilir. Derste önce konu anlatılıyor sonra soru cevaba geçiliyor. Kitap okunuyor, resimler boyanıyor, çeşitlimateryaller hazırlanıyor. Çocuklara yemek yerken paylaşma ve yemek yeme adapları öğretiliyor. Ayrıca çocuklara yönelik hayır çarşıları yapılıyor. Oyun oynarken oyuncak paylaşımı öğretilmeye çalış1lıyor. Teneffüslerde hep birlikte ilahi eşliğinde oyunlar oynanıyor. Tenefüsten sonra konunun devamı bazen tekrarı yapılıyor, şayet konu kısa ise başka bir konuya geçilebiliyor. Kur'an-ı Kerim dersindeharfleriyeni tanıyan çocuklara oyun hamuru, sulu boya, şarkı, oyunlar ve bizzat çocukların yazmaya çalışması gibi aktivitelerle harfler tanıtılıyor. 4-6 yaş grubunda çocukların bir kısmı Kur'an'a geçme başarısı gösteriyorlar. Her gün çocukların alışması için seslibirşekilde kısa surelerle iki rekat namaz kılınıyor.

\section{Sonuç ve Değerlendirme}

Okul öncesi dönemi insanın kişiliğinin, hayata bakışının, dini tutumlarının tohumlarının atıldığı çağdır. Bu dönemde çocukların düşünme biçimleri, duyguları, hayatı ve dini anlamlandırmaları yetişkinlerden çok farklıdır (Dönmez, 2013, s. 523). Bu nedenle çocukta dini duygu ve düşüncenin oluşumu ve gelişiminde, aile içindeki yetiştirmeden sonra, okul öncesi kurumlarındaki eğitim ve öğretim son derece önemlidir. Makalede de izah edildiği üzere, Anaokulu ve yuvalar, çocuğun bedensel ve zihinsel gelişimine ve hazır oluş seviyelerine uygun olarak sağladığı yetiştirme programlarıyla, fitrattan kaynaklanan din duygusuyla ve bireyin dini eğitimiyle de ilgilenmektedir. Çocukların beden, zihin ve duygu bakımından dengeli bir şekilde yetiştirilmeleri, eğitimde bütünlük ilkesine uygun olarak hem ailede ve hem de okul öncesi eğitim kurumlarında uygulanmasıyla mümkün olacaktır (Tavukçuoğlu, 2002, s. 62). Bu yüzden, çocuğun dini açıdan ilk modelini oluşturan ebeveyn, kapsamlı ve planlı yaygın din eğitimi faaliyetleriyle gereken biçimde eğitilmelidir. Okul çevresi ve öğretmenler de, anne-baba kadar çocuk üzerinde etkili olduğu için, okul ve aile işbirliği içinde olunmalıdır (Yiğit, 2006, s. 200). 
Okul öncesi dönem, hayatın tamamını etkileyebilecek deneyimlerin yaşandığı, kişiliğin, inançların temelinin atıldığ ta çok hızlı gelişmekte, (Önder, 2011, s. 379) çocukların en temel özellikleri ve yetenekleri şekillenmekte ve ileriki yıllarda karakterini oluşturacak derecede etkili olmaktadır (Bilgin, 1987, s. 11). Çocuğun dine ve dini kavramlara olan ilgisi de bu dönemde belirmeye başlar ve çocuk hayatın her parçasını keşfetmeye çalıştığı gibi dini ve dini kavramları da keşfetmeye çalışır (Dönmez, 2013, s. 538). Diğer gelişim basamaklarında olduğu gibi, dini inanç gelişimi açısından da çocukluk döneminin kendisine has bazı özellikleri vardır. Bunların başında, çocukların kolay inanırlığı, ben merkezci bir yönelimi, spontane bir dini tecrübe ile antropomorfik bir Allah anlayışına sahip olma gibi özellikler gelmektedir. Dolayısıyla çocukların dini eğitiminde, tüm bu farklı özellikler göz önüne alınarak, çağdaş eğitim ilke ve prensipleri ışığında "kısa, öz, anlamlı, sevgiye dayalı, sade ve açık” bir din eğitimi ve öğretimi verilmeye çalışılmalıdır (Köylü, 2004, s. 154). Yanı sıra çocuklara "seven, affeden, insanı her şeyden üstün tutan" bir Allah inancı aşılanmaya çalışılmalıdır (Dönmez, 2013, s. 539). Çünkü düzgün öğretilmiş bir Allah inancı, kişinin yaratılıştan gelen tabii duygularıyla birleştiği zaman insanın şahsiyetinin oluşumunda çok büyük etkisi vardır (Ayhan, 1998, s. 108).

Anaokulları günümüzde okul öncesi çocuklarının oyun gereksinimini en iyi karşılayan kurumlardır. Kent yaşayışının sıkışık düzeni, oyun alanlarının azlığı ve çalışan anne sayısının çoğalışı yuvaların önemini artırmıştır. Ancak anaokullarına ve yuvalara, çalışan annelerin çocuklarını bıraktıkları, ya da varlıklı ailelerin çocuklarını baştan savdıkları bir yer olarak görmemek gerekir. Keza kimi ebeveynlerin yaptığı gibi, anaokullarını bir okul olarak algılayıp, çocuklarına her gün yeni bir şey öğretilmesini beklemekte doğru değildir. Anaokullarının amacı çocukta öğrenmeye ilgi uyandırmak ve çocuğun içinde var olan yeteneklerin serpilmesine yardım etmektir. $\mathrm{Bu}$ nedenle öğretimi düşündürdüğü için Anaokulu yerine Avrupa ülkelerinde kindergarten (çocuk bahçesi/yuvası) demek tercih edilmiştir (Yörükoğlu, 2002, s. 72).

Dünyada yapılan bilimsel araştırmaların sonuçları, çocukluk yıllarında kazanılan davranışların büyük bir kısmının yetişkinlikte, bireyin kişilik yapısını, alışkanlık inanç ve değer yargılarını biçimlendirdiğini ve sağlam bir kişiliğin temelinin ilk çocukluk yıllarında atılabileceğini göstermiştir (Selçuk, 1990, s. 105). Avrupa ülkelerinde Müslüman aileler bugün bile küçük çocuklarını kiliselere bağlı olan Almanya ve Avusturya'da Kindergarten denilen okul öncesi eğitim kurumlarına göndermek zorunda kalmaktadırlar. Özellikle kiliselerin denetiminde olan bu okullarda, Müslüman çocuklar her ne kadar dini merasimlere katılmasalar bile pek çok Hıristiyan âdetini, arkadaşlarıyla birlikte paylaşmak zorunda kalmakta ve bundan ister istemez etkilenmektedirler (Sezgin, 1991, s. 137). Çünkü bu okullarda hemen her şey Hristiyanlığ1 sembolize etmektedir (Başkurt, 1995, s. 116-117). Dönemin özelliği itibariyle olumlu duygusal bir yapı içinde bulunan çocuklar, uyumlu ve arkadaş canlısıdırlar (Gülay, 2010, s. 134). Bu konunun ciddiyetini maalesef kavrayamayan ailelerin sayısı azımsanacak oranda değildir (Tavukçuoğlu, 2005 , s. 248). Çocuklar için çok önemli bir dönem olan bu yaşlarda onların farklı bir dinin telkinleriyle yetiştirilmeleri kişilik problemlerine yol açmaktadır (Ay, 1998, s. 212).

Avrupa ülkelerinde yaşayan Müslüman çocuklarının ailelerinin ve fertlerinin din, dil, örf ve adetleri ile manevi değer ölçüleri, yani milli kültürleri, bulundukları ülkenin insanından çok farklıdır. Yaşama biçimi itibariyle farklı bir çevrede yaşamaktadırlar. Yerel halk ise Müslümanlar hakkında çok eksik ve maksatlı bilgilere sahip olmaları, din ve dil ayrılıkları gibi sebeplerle Müslümanlara karşı çoğu zaman menfi ve değişik tavırlar geliştirmektedirler. Özellikle 11 Eylül Hadisesi sonrası hızla artarak Avrupa ülkelerinde yayılan İslamofobi (Müslümanlardan korkma ve kaçma içgüdüsü), (Aydın ve Yardım, 2008, s. 8) psiko-patalojik bir hal almaya başlamıştır. Müslümanlar için bu ülkelerde din eğitiminin verilmesi konusunda yasal olarak bir engel bulunmasa bile, İslamofobik eylem ve söylemler bürokratik engellemelere yol açmaktadır.

Avrupa'da özellikle son yıllarda, İ́lâm ile çeliştiği açık olan bazı Batı norm ve değerlerinin, “Avrupa norm ve değerleri” adı altında, İslâm eğitim ve öğretimindeki bazı hakların kullanılmasına engel oluşturulmaya başlanmıştır. Bu anlamda "İslâm eğitimi veya İslâmî eğitim Batı norm ve değerleriyle ters düşüyor" söylemi sıkça gündeme getirilmekte ve böylece Müslümanların din eğitimi anlamında yeni taleplerinin önü kesilmektedir. (Hıdır, 2008, s. 70). 2015 yılında Avusturya entegrasyon ve Dış İşleri Bakanı olan şu anki Avusturya Başbakanı Sebastian Kurz ve bazı kesimlerin çalışmaları neticesinde, selefî ve radikal eğilimler bahane edilerek patlak veren anaokulu krizine kadar yukarıda bahsedilen anaokulları toplumun her kesiminde İslam anaokulları olarak kabul ediliyor ve Din eğitimi dersleri veriliyordu. 2015'ten sonra maalesef Müslümanların

18 | P a g e

www.iiste.org 
bahsedilen birçok zorlukları aşarak kurmuş oldukları bu anaokullarında din eğitimi yasaklanmıştır. Katolik ve Yahudi anaokulları ise görünüşte devlet yardımı almadıkları için dinî eğitime devam etmektedirler. Aslında Müslümanlar da anaokullarında devlet yardımı almadan din eğitimine devam edebilirler ama bu şekilde neredeyse hiçbir anaokulu ayakta kalamaz. Anaokullarında din eğitiminin yasaklanma gerekçelerini ve haklılık paylarını daha iyi anlayabilmek için o yılki basına yansıyan haberlere bakmakta fayda görülmektedir.

12 Aralık 2015 tarihli “Kleine Zeitung” gazetesinin haberine göre, Kurz Viyana'daki yaklaşık 150 İslâmî anaokulundan 71'inin İslâmî kuruluşlara ait olduğunu ve bunun da paralel toplumsal yapılanma açısından endişe verici olduğunu dile getirmiştir. Bu Anaokullarını kimin ve nasıl yönettiği konusunda bilgi sahibi olmak isteyen Kurz, araştırma görevini ön soruşturma şeklinde İslam Eğitim Enstitüsünde görevli Ednan Aslana vermiştir. Ednan Aslan'ın elde ettiği verilere göre, bazı anaokulları resmi olarak okul olmakla beraber, Türk yapısı ve yaşam şekline uygun eğitim verdiğini göstermektedir. Bu Anaokullarında sürekli olarak başka irklardan ve toplumlardan gelen çocukların en aza indirilmesi hedeflenmektedir. Bazı anaokullarını ise sürekli olarak ve daha fazla kendi içlerine kapanık durumda nitelendiren Aslan, az sayıda kalifiye personel ile bu okulların Kur'an okulu haline getirildiğini savunmuştur. Yukarıda incelenen anaokulları göz önüne alındığında burada söylenenlerin farklı amaçları olduğu düşünülmektedir.

Bu düşünceyi doğrulayan bir araştırma, "Dasbiber”' in Tunus kökenli muhabiri Nour Khelifi ve Baş muhabiri Simon Kravagna tarafından yapılmıştır. Avusturya'nın ünlü aylık magazin dergilerinden "Dasbiber"'in 11.12.2016 tarihli nüshasında, "Inside 'Islam' - Kindergärten” başlığı altında yayınlanan bu araştırmanın amacının, İslam Din bilimcisi Ednan Aslan’ın Standard gazetesine verdiği bir röportajda "Radikalizm anaokulunda başlar" iddiasının doğru olup olmadığını ispatlamak olduğu belirtilmiştir. Tunus kökenli muhabiri Nour Khelifi ve Baş muhabiri Simon Kravagna kendilerini Müslüman bir aile gibi göstererek, Samir adlı çocuklarını bu okullara kaydetmek bahanesiyle 14 Müslüman anaokulunda gizli röportajlar gerçekleştirmişlerdir. Araştırmada okulların kalitesini öven muhabir Nour Khelifi, "Eğer Samir diye (bir çocuğum) olsaydı onu kesinlikle buraya gönderirdim" şeklinde kanaatini ortaya koymuştur. Araştırmanın sonunda Ednan Arslan ile bir röportaj da yapılmıştır.

Anaokulları ile ilgili farklı bir bakış açısı da, 1946'dan bu yana Avusturya'da yayınlanan "Die Presse" günlük gazetesinin 12 Aralık 2015 tarihli sayısında "Islam: Mehr Kontrollen für Kindergärten (İslam: Anaokulları İçin Daha Fazla Kontrol)" başlığı altında sunulmaktadır. Haberde Viyana halkının anaokullarının İslâm anaokullarının kontrollerinin daha sıkı yapılmasını istediğinden bahsedilmektedir. Habere göre, Sebastian Kurz'un en son düşüncesi paralel toplum yapısında olan (!) İslami anaokulları hükümet tarafından da tartışılmış, Kurz'un radikalleşme kanıtı olarak ileri sürdüğü Ednan Arslan'ın çalışması hükümet tarafindan tam inandırıcı ve somut bulunmamıştır. Hükümet tam aksine çalışmanın daha fazla sorun teşkil edeceğini düşünmüştür. Gazete haberine göre, Aslan'ın iki defa çıktığı şehir meclisinde çalışması reddedilmiştir.

Anaokullarında din eğitiminin yasaklanma gerekçelerini ve haklılık paylarını objektif olarak sunabilmek üzere birçok haberden bazı önemlilerinden alıntılar yapıldı. Din eğitiminin yasaklanması sonucu İslâm anaokullarının geldiği durumu göstermesi açısından son olarak Avusturya'da aylık bağımsız gazete olarak çıkan "Yeni Hareket" adlı gazetenin, Kasım 2016 sayısındaki "Besmele ve Duaya Yasak" başlığı ile yayımlanan haber değerlendirilecektir.

Anaokullarında (Kindergärten) Müslüman çocukların her türlü dini eğitim fiilen yasaklanmış durumda. Yasaklar o dereceye vardı ki çocuklara yemeğe başlarken besmele çekmesini öğretmek ve günlük hayattaki duaları ezberletmek dahi yasaklandı. Duvarlardaki İslami yazıyla yazılmış tablolara da müdahale ediliyor. İsminin açıklanmasını istemeyen anaokulu yetkililerinin verdiği bilgiye göre Özel anaokullarına denetime gelen müfettişler "Wiener Bildungsplan" adındaki plana uygun davranılıp davranılmadığını teftiş ediyorlar. Wiener Bildungsplan Avusturya'nın değerlerinin öğretilmesini öngörüyor. Özel anaokulu ve kreş sahipleri Viyana Belediyesinden maddi destek aldıkları ve bu destek olmadan kreşi devam ettirmeleri neredeyse imkânsız olduğu için müfettişlerin direktiflerine boyun eğmek zorunda kaliyorlar.

Netice olarak Avrupa ülkelerinde azınlık halinde yaşayan Müslümanların din eğitimine dair iç ve dış problemlerinin çözümünde şu hususları vurgulamak gerekli görülmektedir.

1. Avrupa Birliği ülkelerinde yaşayan Müslümanlar, henüz tam anlamıyla batının oryantalist (şarkiyatçılık) çalışmalarına benzer karşıt bir çalışma (oksidentalizm / garbiyatçılık) içerisine

19 | $\mathrm{P}$ a g e

www.iiste.org 
girememişlerdir. Avrupa ülkelerini, inanç-ibâdet, örf-âdet, tarih, coğrafya, iktisat, siyâset ve sosyokültürel olmak üzere bütün yönleriyle araştırabilecek “oksidentalistik müesseseler” kurulamamış olması bugün bu ülkelerde, başta din eğitimcisi yetiştirme problemi olmak üzere pek çok alanda etkisini devam ettirmektedir.

2. Batı dillerinde İslâm eğitimine ait alternatif ıstılahları üretememe ve din eğitiminde Batı'lı teolojik 1stılahları kullanarak, İslâm'a Hıristiyan gözlüğüyle bakma problemi de çözüm için Müslüman oksidentalistleri beklemektedir. Bu anlamda Avrupa ülkelerinde sağlıklı bir din eğitimi gerçekleştirebilmek için, ülke dilinin ve kültürünün iyi derecede bilinmesi gerekmektedir. Yanı sıra iyi bir ilmi-bilimsel dinî eğitim altyapısı oluşturulmalı ve batı teoloji eğitiminde kullanılan teori ve akımlara dair yeterli derecede arka plan bilgisi edinilmelidir.

3. Avrupa'da yaşayan Müslümanların göçmen statüsünden, yerleşik vatandaşlar konumuna geçmeleri; nitelik olarak da Müslüman nüfusun işçi kalmakla yetinmeyip, hayatın her alanına yayılması Avrupa'da İslâmî bilgi temelinde yapılacak İslâm eğitimi de kaçınılmaz olmuştur. Bu eğitim, İslâm ahlâkı ve değer yargılarının Müslüman nesillere doğru bir şekilde aktarılması ve İslâmî kimliğinin muhafazası için hayati önemdedir.

4. Kök ülkelere aşırı bağlılık son dönemlerde özellikle din eğitimi açısından bir problem haline gelmiştir. $\mathrm{Bu}$ argümanı öne süren Avrupalı yetkililer din eğitimi konusunda bazı adımları engelleyici bir tavır takınmaya başlamışlardır. Avrupa'da yaşayan ve ikinci ve üçüncü nesli oluşturan Müslümanların önemli bir kısmı ne içinde yaşadığı topluma tam uyum sağlayabilmiş, ne de kendi kimliğini tam bulabilmiştir. Avrupa'da yaşayan Müslümanların bulundukları ülkelere entegre olabilmeleri kendi dinî ve kültürel haklarını daha etkin biçimde kullanmalarına yarar sağlayacaktır.

\section{Kaynaklar}

Alpaydın, Y. (2015). Çocukların Dini Gelişiminde Ebeveynlerin Rolü Beklentiler ve Zorlanma Alanlart, İstanbul

Apaydın, H. (2001). Aile İçi İletişimin Çocuğun Dinsel Gelişimine Etkisi, Ondokuz Mayıs Üniversitesi Illahiyat Fakültesi Dergisi, 12-13, 319-337

Argyle, M. (1978). Dinin Yedi Psikolojik Temeli. Çev. Mehmet Dă̆, Ĕ̆itim Hareketleri Dergisi, 23, 272-273

Armaner, N. (1980). Din Psikolojisine Giriş, Ankara

Arslantürk, O. (2008). Avrupa'da Müslüman Aile ve Çocuk Eğitimi, Almanya

Aşıkoğlu, N. Y. (2005). Avrupa'daki Türk Çocuklarının İslâm Din Eğitimi (Temel Sorunlar ve Çözüm Önerileri). III. Din Şûrast: Tebliğ ve Müzakereleri, 20-24 Eylül 2004/Ankara, 3, 469480

Ay, M. E. (2001). Ailede ve Okulda İdeal Din Ë̆itimi, İstanbul

Ay, M. E. (1994). Aile Ortamında Yerine Getirilen İbadetlerin Çocuk Üzerindeki Etkileri. Din Eğitimi Araştırmaları Dergisi, 1, 163-170

Ay, M. E. (1998). Avrupa Ülkelerinde Yaşayan Türk İşçi Çocuklarının Kimlik Problemi ve Çözümü İçin Bazı Teklifler. Uludağ Üniversitesi Illahiyat Fakültesi Dergisi, (7) 7, 207-223

Ay, M. E. (2005). Ailede verilecek Din Eğitiminde Genel Prensipler. Íslam 'da Aile ve Çocuk Terbiyesi (II), 2005, s. 361-374

Ay, M. E. (2013). Okul Öncesi Dönemde Din Eğitimi. Yaygın Din Ĕ̆itimi Sempozyumu -II (30 Mart - 01 Nisan 2012, Ankara), 567-579 
Aydın, A. R. (1996). Çocuğun Dinî Şahsiyet Kazanmasında Ailenin Önemi, Ondokuz Mayıs Üniversitesi Illahiyat Fakültesi Dergisi, 8, 211-219

Aydın, A. R. (2003). Çocuğun Dini Kişiliğinin Gelişmesinde Aile Faktörü, EKEV Akademi Dergisi, (7) 15, 105-112

Aydın, M. Z. (2003). Ailede Ahlâk Eğitimi. Cumhuriyet Üniversitesi İlahiyat Fakültesi Dergisi, 2003, (7) 2, 125-158

Aydın, M. Z. (2009). Ailede Ahlak Ĕgitimi, İstanbul

Aydın, M. Z.; Yardım, M. (2008). Belçika'da İslamofobi ve Müslümanlara Yönelik Ayrımc1lı. Cumhuriyet Üniversitesi İlahiyat Fakültesi Dergisi, 1(2) 1, 7-32

Ayhan, H. (1971). Ailede Din Eğitimi. Diyanet İlmi Dergi, (10) 114-115, 409-413

Ayhan, H. (1992). Batı Avrupa Türkleri F. Almanya'da 30. Yıl, Avrupa Türk-İslam Birliği, Frankfurt

Ayhan, H. (1998). Çocuk Gelişim ve Eğitimi, İstanbul

Bahçekapıl1, M. (2012). Avrupa'da Din Eğitimi, İstanbul

Başaran İ. (1971). Eğitim Psikolojisi, Ankara

Başkurt, İ. (1995). Federal Almanya'da Din Eğitimi, İstanbul

Bayraklı, B. (2005). Kur'ân-1 Kerim'e Göre Ailede Çocuk Eğitimi. Íslam 'da Aile ve Çocuk Terbiyesi (II), 179-188

Bayraktar, M. F. (1995). Ailenin Eğitim Görevi. Din Eğitimi Araştırmaları Dergisi, 2, 117-142

Bilgili, F. M. (2005). Çocuğun Din Eğitimi ve Karşılaşılan Güçlükler, İstanbul

Bilgin, B. (1987). İslam'da Çocuk, Ankara

Bolat, Ö. (2016). Mutlu ve Başarılı Çocuk Yetiştirmek İçin Rehber, İstanbul

Bolay, S.; Türköne, M. (1995). Din Eğitimi Raporu, Ankara

Clark, W. H. (1981). Çocukluk Dönemi Dini- I. Çev. Neda Armaner, Ankara Üniversitesi Illahiyat Fakültesi Dergisi, 24, 175-185

Çamdibi, M. (2005). Ailede Çocuğun Ahlâkî Terbiyesi. İslam'da Aile ve Çocuk Terbiyesi (II), $2005,127-133$

Çaplı, O. (1973). Çocukların ve Gençlerin Eğitimi, Ankara

Çetintaş, İ. (2011). Avrupa'da Yaşayan Türk Göçmenlerin Sosyo- Kültürel ve Dini Sorunları Hakkında Analitik Bir Değerlendirme -İsviçre Örneği. Kahramanmaraş Sütçü İmam Üniversitesi İlahiyat Fakültesi Dergisi, (9) 17, 57-87

Deniz, M. E. (2009). Erken Çocukluk Döneminde Gelişim, Ankara

Doğan, C. (2010). Ailenin Önemi ve Vazgeçilmez Fonksiyonları. Aile ve Eğitim-Tartışmalı İlmi Toplantl-, 2010, 19-29 
Dönmez, F. (2013). Okul Öncesi Dönem Çocuklarının Dini Tasavvurlarına Din Eğitimi Açısından Bir Yaklaşım. Yaygın Din Eğitimi Sempozyumu -II (30 Mart - 01 Nisan 2012, Ankara), 523-541

Duman, M. Z. (1991). Ailede Çocuk Eğitimi ve Lokman Hakim'in Oğluna Nasihatlerinin Düşündürdükleri. Diyanet İlmi Dergi, (27) 3, 103-116

Girgin, A. (2006). Çocuğumu Anllyormuyum, İstanbul

Girgin, A. (2012). Annelik ve Babalık Bir Sanattır, İstanbul

Gözütok, Ş. (2002). İlk Dönem İslam Ë̆itim Tarihi, Ankara

Guy, J. (1996). Çocuk Psikolojisinin Ana çizgileri, İstanbul

Gül. E. (2006). Çocuk Ĕğitiminde Kırk Hadis, İstanbul

Gülay, H. (2010). Okul Öncesi Dönemde Akran Ilişkileri, Ankara

Güner, M. (2017). Avusturya'da yaygın ve örgün olarak yapılan okulöncesi din eğitimi (Yayımlanmamış Yüksek Lisans Tezi), Onsekiz Mart Üniversitesi, Sosyal Bilimler Enstitüsü, Çanakkale

Haktanır, G. (2010). Okul Öncesi Eğitimine Giriş, Ankara

Heinelt, G. (2003). Okul Öncesi Dönemde Çocuğun Gelişiminin Psikolojik Temeli. Çev. Şuayip Özdemir, Din Bilimleri Akademik Araştırma Dergisi, (3) 2, 209-232

Hıdır, Ö. (2008). Avrupa'daki Müslüman Azınlıkların Din Eğitiminin Problemleri Üzerine. Dem Dergi, (1) 3, 64-71

İbrahim H. D. (2014). Erken Çocukluk Eğitimi, Ankara

Kafkasyalı, A. (1997). Çocuk Eğitimi. EKEV Akademi Dergisi, (1) 1, 173-187

Karacoşkun, M. D. (2005). Okul Öncesi Dönem Çocuklarında Dua, Cumhuriyet Üniversitesi Ilahiyat Fakültesi Dergisi, (9) 1, 101-124

Karaköse, Ş. (2010). Çocukluk Dönemi Din Öğretimi. Etkili Din Öğretimi, 21-72

Kaya, C. ve Uzunoğlu, S. (2012). Çocuklar Ne İster, İstanbul

Kaya, M. (1997). Ailede Anne-Baba Tutumlarının Çocuğun Kişilik ve Benlik Gelişimindeki Rolü, Ondokuz Mayıs Üniversitesi Illahiyat Fakültesi Dergisi, 9, 193-204

Kılavuz, M. A. (2005). Anne Baba Örnek Davranışlarının Çocukların ve Ergenlerin Dinî Kişiliğinin Oluşumuna Etkileri, Uludağ Üniversitesi İlahiyat Fakültesi Dergisi, (14) 2, 4158

Kınalızade, A. E.. (tarihsiz). Devlet ve Aile Ahlâkı, Tercüman 1001 Temel Eser, İstanbul.

Koç, A. (2010). Okul Öncesi Dönemde Ailede Çocuğun Din Eğitimi. Karadeniz Teknik Üniversitesi Rize İlahiyat Fakültesi Çocuk Sorunları ve Íslâm Sempozyumu, 30 Eylül - 2 Ekim 2005, 627-658 
Köylü, M. (2004). Çocukluk Dönemi Dini İnanç Gelişimi ve Din Eğitimi. Ankara Üniversitesi Illahiyat Fakültesi Dergisi, (45) 2, 137-154

Köylü, M. (2009). Ahlak Eğitiminde Ailenin Rolü, Çağımızın Ahlak Bunalımı ve Çözüm Arayışları -Milletlerarası Tartışmalı İlmi Toplantı, 24-26 Nisan 2009, 387-410

Oruç, C. (2004). Okul Öncesi Dönemde Çocuğun Din Ĕ̌itimi, İstanbul

Öcal, M. (1991). Temel Ĕgitim ve Orta Ögrretimde Din Eğitimi ve Öğretiminde Metodlar, Ankara

Öcal, M. (1996). Ailede Çocukların Dinî ve Ahlakî Eğitimlerinde Karşılaşılan Problemlerin Başlıca Sebepleri ve Çözüm İçin Bazı Teklifler. Din Eğitimi Araştırmaları Dergisi, 3, 187 206

Önder, M. (2011). Okul Öncesi Dönem Çocuklarının Aile Eğitimi, Cumhuriyet Üniversitesi Ilahiyat Fakültesi Dergisi, (15) 1, 377-386

Özbek, A. (2010). Ailede Dini Sorumluluk Eğitimi, Aile ve Eğitim-Tartışmalı İlmi Toplantı-, 2010, 319-339

Özdemir, R. (2010). Aile Okulunda Çocuk Eğitimi, İstanbul

Özdemir, Ş. (2002). Çocuğun Din Eğitiminde Ailenin Rolü. Din Eğitimi Araştırmaları Dergisi, 9, 113-131

Peker, H. (1985). Ailede Din Eğitiminin Psikolojik Esasları. Diyanet İlmi Dergi, 1985, (21) 1, 21-26

Peker, H. (1985). Ailede Din Eğitiminin Psikolojik Esasları II. Diyanet İlmi Dergi, (21) 2, 4149

Potz, R. (2008). “Avusturya”. Avrupa Birliği Ülkelerinde Din-Devlet İlişkisi. Ed. Talip Küçükcan, Ali Köse, 81-97. İstanbul

Poyraz, H. (2003). Okulöncesi Eğitiminin İlke ve Yöntemleri, Ankara

Sağlam, İ. (2001). Okul Öncesi Eğitimi, İstanbul

Sağlam, İ. (2006). Anne-Baba Dindarlığının Çocuklar Üzerindeki Etkisi. Dindarlık Olgusu (Sempozyum Tebliğ ve Müzakereleri, 25-26 Aralık 2004), 163-180

Sağlam, İ. (2013). Okul Öncesi Dönem ve Din Eğitimi. Yaygın Din Ĕ̆itimi Sempozyumu -II (30 Mart - 01 Nisan 2012, Ankara), 547-561

Samuel S. (1975). Karakter, Çev. Mustafa Ertem, İstanbul

Selçuk, M. (1990). Çocuk Eğitiminde Dini Motifler (Okul Öncesi Çağ). İslâmî Araştırmalar, (4) $2,105-117$

Selçuk, M. (2014). Çocuğun Ĕ̌gitiminde Dini Motifler, Ankara

Sezgin, O. (1991). Üçüncü Neslin Eğitimi, Ankara

Sezgin, O. (1992). “Avrupa'daki Türk İşçileri ve Çocuklarının Eğitimi”. Batı Avrupa Türkleri F. Almanya'da 30. Yll, Frankfurt 
Şencan, H. (2012). Din ve Devlet İlişkileri, Karşılaştırmalı Anayasa Çalışmaları. Ankara

Şentürk H. (1997). Din Psikolojisi, Konya

Şimşek, E. (2004). Çocukluk Dönemi Dini Gelişim Özellikleri Ve Din Eğitimi. Din Bilimleri Akademik Araştırma Dergisi, (4) 1, 207-220

Tavukçuoğlu, M. (1994). Avusturya İslam Diyanet Teşkilatı, Din Dersi Öğretmenleri ve Din Görevlileri. Diyanet İlmi Dergi, (30) 1, 65-86

Tavukçuoğlu, M. (1994). Avusturya İslam Diyanet Teşkilatı, Din Dersi Öğretmenleri ve Din Görevlileri. Diyanet Ilmi Dergi, (30) 1, 65-86

Tavukçuoğlu, M. (2000). Avrupa'da Türk Ailesi ve Din Eğitimi (Avusturya Örneği), Konya

Tavukçuoğlu, M. (2002). Okul Öncesi Çocuğunun Eğitiminde Din Duygusu ve Din Eğitimi. Selçuk Üniversitesi İlahiyat Fakültesi Dergisi, 14, 51-63

Tavukçuoğlu, M. (2005). Yurtdışındaki Türk Ailelerinin Sorunları, İslam'da Aile ve Çocuk Terbiyesi (II), 243-256

Tosun, C. (2012). Din Eğitimi Bilimine Giriş, Ankara

Traughan, R. (2008). Ahlakî Gelişim, Dini Düşünce ve Davranışlar. Çev. Abdulvahit İmamoğlu, Tuncay Aksöz, Sakarya Üniversitesi Ilahiyat Fakültesi Dergisi, 17, 17-24

Yavuz, K. (1983). Çocukta Dini Duygu ve Düşüncenin Gelişmesi (7-12 yaş), Ankara

Yiğit, A. (2006). Çocuğun Gelişim Özellikleri ve İletişim İlkeleri Doğrultusunda Ailede Din Eğitimi. Ondokuz Mayıs Üniversitesi Ilahiyat Fakültesi Dergisi, 22, 179-203

Yörükoğlu, A. (2002). Çocuk Ruh Să̆lı̆̆g, İstanbul

Zümrüt, O. (2006). Avrupa'da Din Öğretimi ve Yeni Açılımlar. Ondokuz Mayıs Üniversitesi Ilahiyat Fakültesi Dergisi, 22, 9-35 